\title{
The Untapped Functions of International Cooperation in the Age of Sustainable Development
}

\author{
Adolf Kloke-Lesch
}

\subsection{Introduction: An Agenda That Calls for More}

In this contribution, I challenge the traditional notion of development cooperation by using a functional approach to understanding externally oriented policies, apply this approach to assess whether the means of implementation (MoIs) incorporated in the 2030 Agenda for Sustainable Development are commensurate to its universal character, and elaborate key features of a truly universal concept of international cooperation for sustainable development. After the introduction setting the scene, the next part unpacks the traditional notion of development cooperation from a functional perspective, with a particular view on past contestations in political practice, in order to arrive at a more basic understanding of different forms and roles in the fields of international relations and cooperation. In the third part, this functional understanding is used to roughly compare the ambitions of the 2030 Agenda with the envisaged MoIs, with a particular view to implementation within "developed countries" as well as between them. ${ }^{1}$ The fourth part takes an exemplary look at the ways international organisations and cooperation formats between "developed countries" have embraced and processed the agenda during the first four years since its adoption. The conclusion contrasts the development cooperation concept of the pre- 2015 world with a concept of international cooperation required for the 2030 world.

\footnotetext{
A. Kloke-Lesch $(\varangle)$

Sustainable Development Solutions Network Germany (SDSN Germany), Bonn, Germany

e-mail: kloke-lesch@sdsngermany.de

(C) The Author(s) 2021 
The adoption of the universal 2030 Agenda for Sustainable Development with its 17 Sustainable Development Goals (SDGs) by a world leaders' summit at the United Nations (UN) in September 2015 marked both a big success of, and a great challenge to, development cooperation actors. Under its ambitious headline "Transforming our world", the 2030 Agenda presents itself as "a plan of action for people, planet and prosperity" (United Nations [UN] 2015c). The 2030 Agenda sets "universal and transformative Goals and targets" and stipulates a "Global Partnership for Sustainable Development" under which "all countries and all stakeholders [...] will implement this plan" (UN 2015c). Development cooperation actors need to learn from this success, fully embrace its implications, and transform themselves towards a truly universal international cooperation for sustainable development.

The 2030 Agenda was a success for development cooperation actors because they were able to leave their conceptual path-dependencies, epitomised by the eight Millenniums Development Goals (MDGs), ${ }^{2}$ by joining the processes initiated by the UN Conference on Sustainable Development in 2012 (also known as Rio+20) and incorporating their ambitions, objectives, and approaches in the emerging new universal agenda of sustainable development.

This was by no means preordained. Just a few months before the Rio+20 conference, a High-Level Panel of Eminent Persons on the Post-2015 Development Agenda (HLP) was convened by the UN Secretary-General. ${ }^{3}$ The HLP was, in the first place, understood as a parallel process to what later became the Open Working Group of the General Assembly on Sustainable Development Goals (OWG). ${ }^{4}$

The two processes differed markedly. The HLP worked for "a poverty/basic needs agenda, serving to coordinate international aid efforts", whereas the OWG aimed at "a sustainable development agenda incorporating poverty, environmental sustainability, economic development, and social equity" (Fukuda-Parr and McNeill 2019, p. 9). The terms of reference for the HLP even called on the panel "to advise the Secretary-General on how the SDGs relate to the broader Post-2015 development agenda". This mandate putting the post-2015 development agenda somewhere "above" the SDGs was soon to be overtaken by history, as the OWG became the one and only intergovernmental process shaping the new integrated agenda. The report of the HLP (High Level Panel 2013) acknowledged, and eventually supported, this comprehensive approach with, for example, the notion of "One World: One Sustainable Development Agenda". Hence, the HLP's report reflects the beginning of a real acceptance by many-in particular in the traditional development cooperation community - that a transformational agenda might be possible (Dodds et al. 2017). The 2030 Agenda can thus be seen as a result of a contestation of traditional narratives and norms of development policy and cooperation that led to the successful evolution of a new normative framework. 
One of the major challenges presented by the 2030 Agenda to development cooperation as well as to other actors lies in the fact that its universal, integrated, and indivisible character constitutes sort of a Copernican turn in the thinking of (global) development that is not accompanied by a comparable overhaul of the institutional and instrumental set-up of the pre- 2015 world. Surely, this would not constitute a fundamental problem for the implementation of the 2030 Agenda if the SDGs would only need to be achieved in the "developing countries". Quite the opposite is the case. As the SDGs are calling for actions by all and benefitting all (Von der Heijden et al. 2014), most of them can only be achieved globally if also achieved in and by the "developed countries".

However, the normative framework of the 2030 Agenda is barely recognised as a contestation or challenge also to the norms and institutions governing relations and cooperation between the "developed countries". This should be of serious concern since implementing the transformative 2030 Agenda within the framework of the pre-2015 institutions and instruments puts the world at risk of also ending up in a pre-2015 world again.

Therefore, both the scholarly and political debates on the international implementation of the 2030 Agenda (Cooper and French 2018; StaffordSmith et al. 2017) should move beyond "North-South" and "South-South" cooperation and address the agenda's repercussions also on "North-North" cooperation. To this end, development studies, when shaping their role in the decades to come (Baud et al. 2019), also need to more fundamentally reviewand most probably reframe-some of the basic tenets and terminologies they have stuck to for decades. ${ }^{5}$

In order to take a bird's eye view on the changing patterns and necessities of international cooperation, scholarly debates more than ever need to make dated as well as more recent diplomatic and bureaucratic terminologies their subjects by using their own conceptualities and terminologies instead of following or mirroring the political discourse. This is all the more needed and demanding, as multiple contestations to the paradigms of development and development cooperation have led to sort of a Babylonian Confusion aggravating the difficulties of understanding and working in a rapidly changing world. This contribution does not aim to resolve this. Rather, it should be read as a call to open a door to new thinking, research, and practice.

\subsection{What Is Development Cooperation? A Functional Approach to External Policies}

Throughout the past decades, a primarily normative conceptualisation of development cooperation has been one of its most distinctive features visà-vis other policy fields, which are basically defined or understood in functional terms. Nevertheless, also development cooperation is a manifestation of governmental functions. The underlying assumption of this functional approach is that in all states (as "political systems") "the same functions are 
performed $[\ldots]$ even though these functions may be performed with different frequencies, and by different kinds of structures" (Almond 1960, p. 11), and that this can also be applied to the external behaviour of states, which in the twenty-first century may go well beyond the function of "protecting the integrity of political systems from outside threats, or expanding into and attacking other societies" (Almond 1960, p. 5).

Thus, in order to arrive at a functional understanding of development cooperation, the core question is not "What is the purpose of development cooperation?" but rather "What is development cooperation?" (Kloke-Lesch 1998a, b) ${ }^{6}$ The distinction between the basic (or abstract) function of a policy field on the one hand, and its (changing) substantial purposes (policy goals) on the other hand, is quite familiar in different policy fields. Foreign policy is essentially not understood, for example, as peace policy by definition, but rather in functional terms as the management and shaping of relations to other states ("Diplomacy is intermediation" [Haynal 2002, p. 34]). Nor is economic policy primarily conceived, for example, as growth policy, but rather as governments' actions influencing economic orders, processes, or structures.

By contrast, development cooperation has been normatively framed mainly by purpose, namely the promotion of economic and social development of "developing countries", with the MDGs having had narrowed this normative approach to the eradication of poverty (UN 2015a). The geographical limitation ${ }^{7}$ to (changing) lists of "developing countries" is the inherently inevitable consequence of the underlying normative concept of development, followed by the membership of both the UN and the Development Assistance Committee (DAC) of the Organisation for Economic Co-operation and Development (OECD). Furthermore, for some decades (and for many actors and scholars still today), the measures and instruments used for this purpose have been equalled to aid, or at least have had to show a certain grant element, characterising the so-called donor-recipient relationship.

Contrary to this primarily normative conceptualisation, I am going to suggest a basically functional reading of "development cooperation" that is neither linked to a specific normative concept of development, nor to a limited group of countries in the first place: "development cooperation" as shaping conditions within (other) countries by using cooperative and promotional means. A functional understanding of development cooperation, as well as of external governmental activities at large, seems better suited to answer contestations that the policy field of development cooperation has repeatedly been faced with: contestations to the notion and norm of development itself, in relation to other policy fields, and by new actors and challenges that emerge over time, not least by the 2030 Agenda. After some sketchy observations on these contestations, the functional understanding of development cooperation within externally oriented policy fields is further explained and prepares for a functional assessment of the 2030 Agenda's means of implementation. 


\subsubsection{The Contested Notion of "Development"}

Throughout the decades, development cooperation has mainly been based on a specific, normative notion of development itself (Kloke-Lesch 2019). These traditional discourses understand development mainly as a progressive ("positive"), primarily socio-economic process that needs to happen in the "developing countries" and had happened before in the "developed countries". Also, critical development studies (Veltmeyer and Wise 2018), which argue in favour of alternative development paths, tend to stick to a normative and geographically limited (or at least focussed) notion of development. ${ }^{8}$ At the same time, calls to reconsider and abandon the term "development" are growing, as the term appears to produce more misunderstandings than solutions and to perpetuate the dichotomies of Self/Other or South/North (Schönberg 2019).

In order to break free of these basically normative connotations of "development" and get a better grip on the manifold processes under "accelerated globalisation", the concept of transformation studies tries to contribute towards a rethinking of international development (Alff and Hornidge 2019). Here, transformation is conceived as an open-ended and unpredictable process ("any process of change, including studying it, or attempts to actively shape it") with an emphasis on "the negotiation processes inherent to unfolding change, rather than about its ultimate result or outcome" not "being bound or fixed to particular places, regions or areas" (Alff and Hornidge 2019, p. 142), and thereby also challenging the traditional geographical limits of the notion of development. This challenge also sneaked into the renewed definition of development studies that evolved within the European Association of Development Research and Training Institutes, which mentions as one of the emerging novel concerns "poverty and social exclusion in industrialised countries" while maintaining development studies as "also characterised by normative and policy concerns" (Mönks et al. 2019). ${ }^{9}$ Moving these argumentations even further, one could also turn to a more neutral understanding of the notion of "development" itself as a term covering the change ("developments") occurring or unfolding in any place.

On the normative side, the advent of the universal concept of sustainable development-with its economic, social, environmental, as well as political dimensions - constitutes a contestation to both the purpose and the geographical focus of the traditional concept of development: the 2030 Agenda claims that development everywhere needs to be sustainable. Thus, sustainable development as a concept cannot be confined to "developing countries", giving rise to doubts whether the notion of development can have any separate normative meaning at all alongside the notion of sustainable development. In the same vein, "the concept of the global common good as a normative and analytical framework for development research and policy and international cooperation for global sustainability" (Messner and Scholz 2018, p. 1) constitutes a 
fundamental change of perspective by moving the vanishing point of development and development cooperation beyond "developing countries" alone. These various contestations have contributed to an emerging shift "towards a new paradigm of global development" where the term "international development" and the accompanying concept of development cooperation from the "North" to the "South" became seen as "increasingly inappropriate for encompassing the various actors, processes and major challenges with which our world engages in the early 21 st century" (Horner 2019). In this context, it is worth noting that the notion of global development is-and should always be-broader than a political product such as the 2030 Agenda with its SDGs, which by their very character are an expression of a political compromise struck in a given moment in history. ${ }^{10}$

\subsubsection{Development Cooperation: Normative Overcharge and the Risk of Marginalisation}

Based on a primarily normative concept of development, most development cooperation actors from the "North" have a penchant for occupying the high moral ground and deliberately trying to insulate themselves from political, economic, or other interests and concerns beyond their own remit all too easily denounced as selfish, amoral, or at least short-term, and denied having normative bearings of their own. This basically altruistic self-perception renders development cooperation quite a delicate position with regard to other policy fields. Since giving in to self-interest is seen as an aberration from the path of virtue and questioning their core identity, development cooperation actors hesitate to enter in a give-and-take situation with other departments.

In addition, aid that is also oriented towards securing domestic or national interests is seen as a detrimental ("not always the most efficient, nor the most effective") way to maximise global development ambitions (Gulrajani and Calleja 2019). This claim of maintaining the "integrity" or "purity" of development cooperation by the "North" as, for example, epitomised in the Principled Aid Index (Gulrajani and Calleja 2019), is an underestimated impediment when seeking political compromise. On the other hand, counting in self-interest and non-developmental normative concerns always has beenand continues to be-part of the political reality of development cooperation (Gulrajani and Calleja 2019; Mawdsley 2017). Denying this leads to the often observed hypocrisy in domestic and international development discourses, hampering the credibility more than the very fact itself.

Also, the suggestion to understand development cooperation quite broadly as "a country's policies and how these affect the current and future welfare and growth of other countries' people and economies" and to include actors "that do not have an explicit policy towards other countries $[\ldots]$ because their policies - for example, on climate, migration, and trade-have a bearing on people elsewhere, regardless of their intent" (Mitchell 2021) can be seen as 
an acknowledgement of the realities of cooperation while maintaining a traditional normative orientation. The talk of win-win cooperation and enlightened self-interest tries to overcome this hypocrisy, but it does not change much the basic normative understanding of development cooperation.

It was after the end of the "East-West" conflict, in particular, that development cooperation actors hoped to break free of the geopolitical considerations infringing on their activities and focus on their core normative purpose, which inter alia led to the Millennium Declaration (UN 2000) and the MDGs. However, the two decades following the MDGs have shown something different and confronted a normatively overcharged notion of development cooperation with new contestations. Insulating development cooperation from infringements by other policy fields, while at the same time confronting them with far-reaching developmental demands, can lead to isolation and marginalisation of the policy field or, eventually, to its subordination to others.

\subsubsection{Time and Again Too Narrow to Cope with New Challenges}

Lastly and most importantly, a normative and geographically limited selfconceptualisation of development cooperation makes it difficult for development cooperation actors to deal with emerging new challenges and new actors. This could, for example, be observed after 1989, when Western donors started to support and promote transformation in Central and Eastern Europe and in the countries of the former Soviet Union by deploying institutions and instruments of development cooperation. This engagement of development cooperation actors was heavily contested, both from within and beyond the traditional development community, arguing that these countries were not "developing countries", the purpose of the engagement was not poverty reduction, and including them in the official development assistance (ODA) would crowd out traditional recipients. ${ }^{11}$

The primarily normative and geographically limited understanding of developing cooperation encapsulated in the ODA concept also holds sway over the discourses on the increased heterogeneity of "developing countries" (van Bergeijk and van Marrewijk 2013; Fialho and van Bergeijk 2017). There, it leads to calls to focus development cooperation on low-income countries, to graduate middle-income countries from the list of ODA recipients, and to "hand over" cooperation with them to departments beyond the aid agencies. A comparable debate runs about whether, or to what extent, support for global public goods such as climate or biodiversity (Kaul 2017), activities in the context of military interventions such as in Afghanistan or Iraq (Dalrymple 2016; Kisangani and Pickering 2015), or, more recently, measures in the context of migration (CSO Partnership 2017) should be considered part of development cooperation.

Furthermore, and not only in these topical contexts, foreign affairs as well as line ministries of DAC countries have created budget lines and set up operational structures to implement projects in "developing countries" and to fund 
respective multilateral institutions, thus bypassing aid departments and agencies, and furthering the "fragmentation of aid" (Klingebiel et al. 2016). To a significant extent, the emergence of these actors can be seen also as a reaction to the hesitation and refusal by traditional development actors to embrace new topics, for example in the areas mentioned above and the related concerns of other departments. Consequently, and although most of these activities are reported as ODA, aid departments are struggling to coordinate and embed them into their broader frameworks of development cooperation.

These contestations from within the individual DAC countries are accompanied and reinforced from beyond the DAC by the increasing relevance of other state actors and approaches often subsumed under "South-South" cooperation. ${ }^{12}$ In its self-perception as well as in the UN, this type of cooperation is explicitly seen as distinct from ODA (UN 2019b) by following the idea of a mutually beneficial cooperation taking quite different, multimodal forms by linking financial and technical cooperation under concessionary terms with non-concessionary means, knowledge sharing, trade, and investment in all kinds of sectors.

The discussed concept of Total Official Support for Sustainable Development (TOSSD) can be understood as an attempt to develop an overarching framework for all external, officially supported finance for sustainable development (UN 2019a). "Southern" actors see this as the "Southernisation" of ODA and an attempt to measure "South-South" cooperation with a concept originally coming from the OECD. Still, the vanishing point also of the TOSSD concept lies in a group of countries categorised as "developing".

\subsubsection{What Is Development Cooperation?}

Given these changing conceptualisations and contestations of development cooperation, it seems useful to look for a more basic feature that is common to all the different manifestations: the function of development cooperation within the externally oriented policy fields (Kloke-Lesch 1998a, b). Such a basic feature needs to be embedded into a broader functional understanding of externally oriented governmental activities. For this, it seems helpful to develop a very basic mapping of the external functions of a state as a "political system", that is, the functions that relate to its external environment and are performed in order to maintain the system (see Table 7.1). These potential functions could be basically described as threefold: first, shaping relations between countries, second, shaping conditions within (other) countries, and third, shaping global conditions.

Shaping relations between countries is the most basic and oldest external function of states, including, on the one hand, the relations between the states (as "political systems") themselves (from mutual recognition and diplomacy through to the threat and use of military force), and on the other hand non-governmental relations between the countries, such as the interactions of economic and societal actors or individual persons (e.g. flow of people, goods, 
Table 7.1 Functional mapping of externally oriented policies and the place of development cooperation

\begin{tabular}{|l|l|l|l|}
\hline \multicolumn{1}{|c|}{ Fields of activity } & $\begin{array}{l}\text { Shaping relations } \\
\text { between countries }\end{array}$ & $\begin{array}{l}\text { Shaping conditions } \\
\text { within countries }\end{array}$ & $\begin{array}{l}\text { Shaping global } \\
\text { conditions }\end{array}$ \\
\hline $\begin{array}{l}\text { Regulation of } \\
\text { governmental and } \\
\text { non-governmental } \\
\text { behaviour }\end{array}$ & & & \\
\hline $\begin{array}{l}\text { Promotion of non- } \\
\text { governmental } \\
\text { behaviour }\end{array}$ & & \\
\hline $\begin{array}{l}\text { Inter-governmental } \\
\text { cooperation }\end{array}$ & & \\
\hline \multicolumn{2}{|c|}{ Core functions of development cooperation } \\
\hline \multicolumn{2}{|c|}{ Related functions (policy coherence for development) } \\
\hline
\end{tabular}

Source Author

services, capital, knowledge, and information). Traditionally, this function is exerted by a state primarily with a view to domestic and national purposes, while in principle respecting the concepts of sovereignty and non-interference with regard to other states.

However, as the internal developments of other countries sometimes matter, shaping the conditions within countries emerged as a second external function of states. This function can be exerted with high, low, or no respect for the principles of sovereignty and non-interference as well as on the basis, for example, of a request/invitation from the one state or a proposition by the other. It may relate to economic or social conditions (e.g. labour standards, security or human rights issues, or environmental as well as migration concerns).

Beyond the conditions within countries, there is increasing interest by states in shaping global conditions. This third external function of states relates to global public goods as well as other concerns that require more than measures just within countries (e.g. climate; oceans, including deep sea mining; biodiversity; global macroeconomic stability and a functioning trading system; health; air traffic security; space; and migration).

When exercising these functions, governments can use and combine a broad array of means. I suggest categorising them as regulatory, promotional, and cooperative. Regulatory means include laws and norms at the national and international levels. Promotional means refer in the first place to financial and other incentives for non-governmental actors (e.g. business, civil society organisations, individual persons) engaged in external activities. Cooperative means, in this context, are specifically understood as intended 
intergovernmental project and programme cooperation aiming at concrete, palpable outcomes.

All three external functions of a state can be performed in unilateral, bilateral, plurilateral, and multilateral ways. The motives can be selfish, altruistic, or enlightened. The objectives may lie at home or abroad. Furthermore, the functions can be intertwined. For example, countries can shape relations to other countries with the aim of changing conditions within these countries, or they can engage in shaping conditions within other countries while aiming at global conditions or pursuing domestic policy purposes.

When applying this understanding of external governmental activities, one can describe the basic function of development cooperation as shaping conditions within (other) countries by using cooperative and promotional civilian means (Kloke-Lesch 1998a, b). These instruments include, above all, (1) realising projects and programmes that are often accompanied by an active influence on the framework conditions in the respective countries and (2) promoting non-governmental activities in these countries. For this functional definition, it does not matter whether it is performed by a dedicated department ("aid agency") or by governmental entities scattered across departments. Furthermore, development policy in a broader sense would also try to influence the regulatory activities, for example by foreign affairs or trade departments, with a view to its pursued objectives ("policy coherence for development").

Thus, this functional role of development cooperation can come into play wherever, whenever, and for whatever reason it is politically desired and possible to influence conditions in specific countries using civilian means, from unilateral through to multilateral ones. Such a functional approach to development cooperation would not start with the question whether countries, or people in countries, are needy, but rather whether there is a necessity or interest felt to impact on developments in countries, irrespective of whether they are listed as "developing" or "developed" countries.

Depriving the notion of development cooperation of its traditional normative core and geographical focus is not meant to allow for policies not strongly rooted in the norms and values that are enshrined, for example, in international law and national constitutions (Burchi et al. 2018). On the contrary, a functional approach can be helpful in better analysing and understanding the realities and normative framings of international relations and cooperation under changing circumstances, in comparing the activities of different actors by using a uniform terminology, and in identifying necessary next steps when implementing a new, ambitious, and universal normative framework such as the 2030 Agenda for Sustainable Development.

\subsubsection{Untapped Potential: A Functional Reading of the 2030 Agenda's Means of Implementation}

The 2030 Agenda marks a fundamental turn from the concept of "international development" organised around the "North-South" binary, poverty 
eradication, and aid for "developing countries" to a universal concept of "global development" with sustainable development at its normative core and requiring a broad range of MoIs in and between all countries: domestic as well as international, non-financial as well as financial, concessional as well as non-concessional, and political as well as technical ones (Kloke-Lesch 2016).

Do the 2030 Agenda and the steps to implement it actually live up to its proclaimed universal ambitions? On the conceptual and normative levels, the broadening of the substantial purpose of development into sustainable development is spelt out throughout the document and has, in principle, been accepted globally. With regard to the universality of the agenda and the geographic shift from "developing countries" to all countries, as well as to global issues and global public goods, the picture is more nuanced. On the one hand, the agenda calls on all countries for implementation ("These are universal goals and targets which involve the entire world, developed and developing countries alike" [UN 2015c]), and almost all of the SDGsincluding their substantial targets-are framed in a universal way. On the other hand, the document maintains the distinction between "developed" and "developing" countries and gives particular prominence to implementation in the latter, while calling on the former to support these endeavours. This lopsidedness gets stronger with respect to the means of implementation, which rely mainly on the Addis Ababa Action Agenda (AAAA) of the Third International Conference on Financing for Development (UN 2015b).

The AAAA is a product of the Financing for Development process, which predates the universal 2030 Agenda and has been limited to the implementation in "developing countries" (Kloke-Lesch 2016). The relation between the AAAA and the 2030 Agenda was a contested issue, in particular with regard to non-financial means of implementation, the role of the "common but differentiated responsibilities" principle beyond environmental issues, and to what extent the 2030 Agenda and the individual SDGs should contain specific means of implementation (Dodds et al. 2017). Eventually, the AAAA was declared an integral part of the 2030 Agenda and, in addition, means of implementation targets were included both under each SDG and SDG 17.

\subsubsection{Lopsided Universality: A Functional Mapping of the Means of Implementation of the 2030 Agenda}

When applying the functional understanding of external governmental activities, the 62 MoIs mentioned in the 2030 Agenda $^{13}$ (see Annex) can be understood as a regulatory framework geared towards the three fields of activities described (shaping relations between countries/shaping conditions within countries/shaping global conditions) by using the three basic kinds of means (regulatory, promotional, and cooperative instruments), leading to nine principle functional fields (plus the overarching MoI 17.14 on policy coherence for sustainable development). In Table 7.2, I assign each MoI to one 
Table 7.2 Functional mapping of the means of implementation of the 2030 Agenda
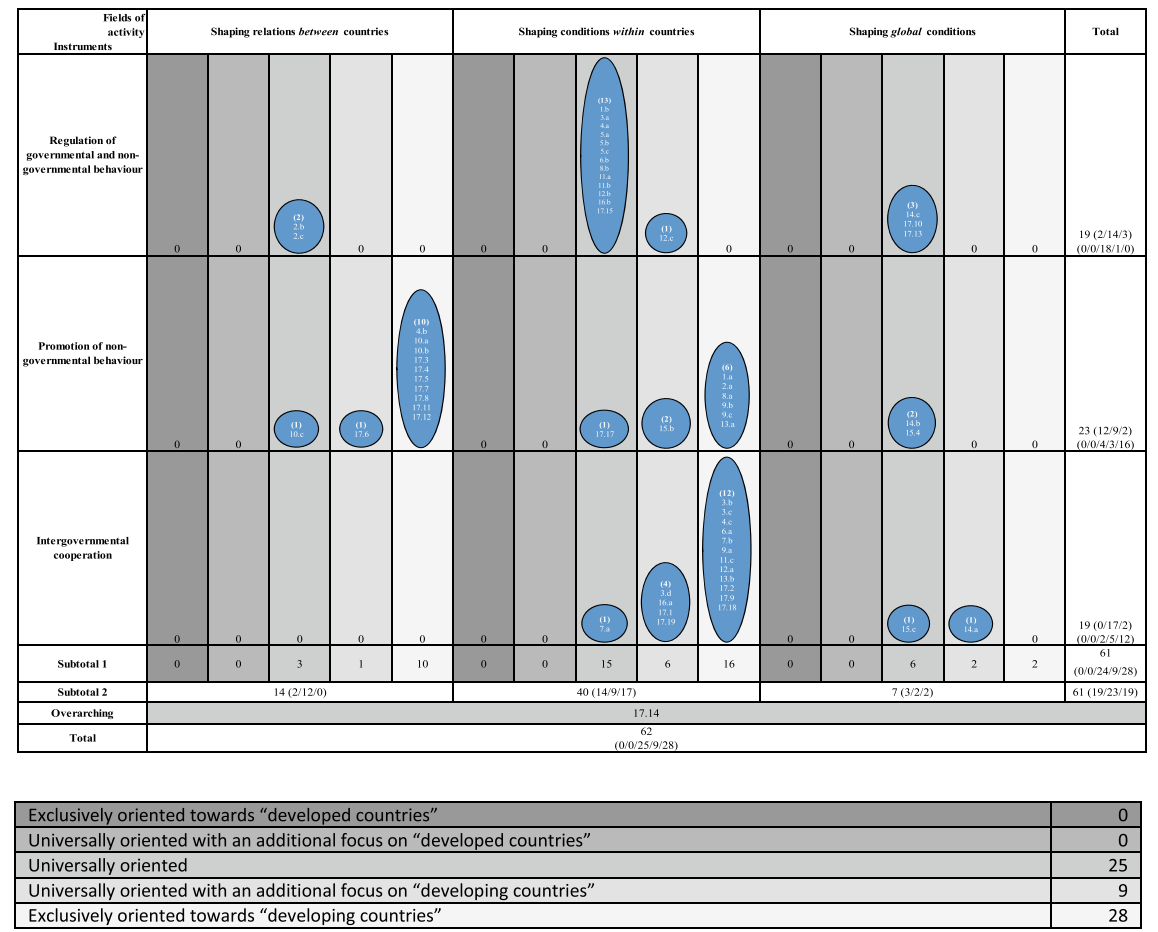

Source Author

of these fields according to its main focus. In addition, all MoIs are categorised according to their universality or focus on a type of country, leading to five categories: (1) exclusively oriented towards "developed countries", (2) universally oriented with an additional focus on "developed countries", (3) universally oriented, (4) universally oriented with an additional focus on "developing countries", and (5) exclusively oriented towards "developing countries". With all the reservations that these different kinds of rough categorisations and assignments entail, the analysis provides at least some general patterns that expose both the overall mindset that led to the MoIs of the 2030 Agenda and the blind spots or missing means of implementation.

With regard to fields of activities, the MoIs of the 2030 Agenda have a clear and strong focus on shaping conditions within countries. Two-thirds (40) focus on implementation within countries, whereas 14 address relations between countries, and only 7 relate to the shaping of global conditions. While a strong focus on domestic implementation is indispensable, the relatively lesser focus of the MoIs on global conditions is deplorable. Although this can be explained by the fact that the negotiations on the 2030 Agenda tried to avoid interfering with other processes, regimes, and institutions, such 
as the ones on climate or trade, it can also be seen as a missed opportunity for injecting a specific 2030 Agenda momentum into these areas and making them accountable to the 2030 Agenda processes. Regarding the types of instruments, the MoIs are quite evenly distributed between regulatory (19), promotional (23), and cooperative (19) instruments. The significantly strong showing of promotional instruments demonstrates the particular focus of the 2030 Agenda on the mobilisation of non-governmental actors, in particular from the business sector and civil society.

When checking the MoIs against the universal aspirations of the 2030 Agenda, three quite significant features emerge: (1) a first majority of the MoIs are framed in a universal way, addressing all countries, "developed" as well as "developing" countries alike; (2) a second, overlapping majority of the MoIs are exclusively, or with a special focus, geared towards "developing countries"; (3) not one of the MoIs is geared exclusively, or with a special focus, towards "developed countries". 14 More specifically: the first majority (34 out of 62) of the MoIs are framed in a universal way, including nine of them giving an additional reference to "developing countries". When taking the latter together with the $28 \mathrm{MoIs}$ that refer exclusively to implementation in "developing countries", one arrives at a second majority (37 out of 62) of the MoIs geared at least partly towards the "developing countries", including those that call for support by "developed countries".

Furthermore, two other features are significant. First, all but one of the MoIs (18 out of 19) that address the regulation of governmental and nongovernmental behaviour (including norm-setting) are framed in a strictly universal mode; most of them (14) are related to the domestic implementation in both "developed" and "developing" countries. Second, most of the MoIs that are geared towards the promotion of non-governmental behaviour (16 out of 23) and international cooperation (12 out of 19) have an exclusive focus on "developing countries", addressing primarily the external relations of, and the conditions within, these countries.

\subsubsection{Unfinished Business: “Developed Countries” Are Not Left off the Hook}

This two-faced character of the means of implementation of the 2030 Agenda-strongly universal on the one hand, and lopsided towards "developing countries" on the other hand when it comes to specificsreveals that the Copernican turn in development thinking being ushered in by the 2030 Agenda is still incomplete with regard to implementation, institutions, and instruments. This incompleteness reflects the interests of, and power relations between, major groups of countries as well as institutional path-dependencies inherited from the pre-2015 world. As "developing countries" have become used to goals being set by the international community for their domestic development (such as the MDGs), this is in many ways quite a new experience for "developed countries", in particular when 
operating within a common framework with "developing countries". For "developing countries", internationally agreed goals—including their commitments to implement them via domestic actions-have been acceptable as long as they are accompanied (quid pro quo) by commitments, although often vague, from "developed countries" to support this implementation through aid and other means. "Developed countries" have more or less accepted these commitments but remained hesitant about accepting means to monitor and enforce their implementation, even more so if they relate to issues where their own domestic and the international development goals conflict (King 2016). Thus, this hesitation by "developed countries" tends to increase even further with the 2030 Agenda, as now monitoring and implementation relate also to issues that are traditionally seen as being primarily domestic ones, without prima facie significant external relevance.

In addition, the pre-existence of the traditional development cooperation architecture with its institutions and instruments rendered it quite easy to draw on them when designing the MoIs of the 2030 Agenda. At the same time, this tended to be reinforced by the institutional interests of actors within this architecture on both the "donor" and "recipient" sides. At the same time, a more detailed inclusion of means of implementation beyond the development cooperation architecture-for example in areas such as international human rights covenants, trade agreements, international finance, or even environmental conventions - was met with some hesitation from many sides, not least by institutional actors in these areas that wanted to avoid "subordination" to a framework not of their own making. Thus, it is quite plausible that the negotiations on the 2030 Agenda (Dodds et al. 2017) settled with a prevalence of MoIs related to "developing countries" and development cooperation but only included a few weaker hints to other institutional arenas.

However, although the MoIs do not make specific references to implementation in "developed countries", these are not released from their respective responsibilities. The letter and the spirit of the majority of the MoIs are truly universal and establish a responsibility, in the sense of "obligation" (Bexell and Jönsson 2017), also of "developed countries" to act on the SDGs domestically and in their relations with each other. Furthermore, the agenda itself calls on all countries to put "cohesive nationally owned sustainable development strategies" at the heart of the efforts and underscores "that, for all countries, public policies and the mobilization and effective use of domestic resources, $[\ldots]$ are central" (UN 2015c).

This is all the more compelling with regard to the "developed countries". Their gross domestic product (GDP) amounts to roughly three-fifths of global GDP, and their trade and foreign direct investment just between them amount to roughly half of both. But it is not only these figures that matter due to their sheer size in addition to the spillover effects on other countries and the planet that go along with them (Schmidt-Traub et al. 2019). Also, the patterns of production and consumption, of trade and foreign direct investment, and, for example, of knowledge production and technological development that prevail 
within and between "developed countries" critically shape the global system and their interactions with other countries.

Furthermore, and most importantly, without being embraced also by the people of "developed countries" as a positive agenda that is beneficial to themselves as well, the 2030 Agenda will not get the required societal and political support. It is therefore of critical importance to link core societal concerns in "developed countries" to the SDGs and integrate them as guiding objectives in the respective domestic policies.

\subsection{INTERNATIONAL COOPERATION STILL Largely Trapped in the Pre-20i5 World}

The first four years of implementing the 2030 Agenda have seen manifold initiatives in the fields of international cooperation and relations to embrace the agenda and translate it into action. However, the agenda's ambition that "all countries and all stakeholders [...] will implement this plan" (UN 2015c) has not been met, and "the transformation required to meet the Sustainable Development Goals by 2030 is not yet advancing at the speed or scale required", as put by UN Secretary-General António Guterres (UN 2019c). The reasons for this unsatisfactory picture have been subject to both scholarly and civil society debates highlighting, for example, the lack of governance and institutional mechanisms in domestic implementation (Kindornay 2019); the voluntarist character of the framework and a lack of both intensification and institutionalisation of cooperation (Cooper and French 2018); much too little attention on interlinkages and interdependencies among goals (StaffordSmith et al. 2017) or on the underlying social structures, power relations, and governance arrangements (Martens 2019).

The functional mapping of the MoIs of the 2030 Agenda proposed in this contribution reveals an additional feature: the international implementation envisaged by the 2030 Agenda remains in many ways trapped in the development cooperation patterns of the pre-2015 world, focussed primarily on cooperative and promotional instruments geared towards shaping conditions in "developing countries". Regulatory and norm-setting MoIs-framed universally and addressing domestic implementation, also within "developed countries" - are not accompanied by cooperative and promotional means of implementation. MoIs addressing particularly the relations between "developed countries" are largely missing. The way international organisations and cooperation formats between "developed countries" have embraced and processed the agenda so far mainly mirrors this lopsided feature, but it also shows the first small and reluctant steps out of the pre-2015 trap.

\subsubsection{United Nations and Bretton Woods Institutions}

It was the UN performing its universal regulatory, primarily norm-setting function in shaping relations between countries, conditions within countries, 
as well as global conditions that led to the adoption of the 2030 Agenda. Many of the MoIs of the agenda are an expression of this function. However, the UN has few means at its disposal to enforce the norms set by the agenda. The only major institutional innovation to support the implementation of the 2030 Agenda is the United Nations High-level Political Forum on Sustainable Development (HLPF). ${ }^{15}$ This intergovernmental body is to play a central role in the universal follow-up and review of the 2030 Agenda, including "voluntary national reviews" undertaken by both "developed" and "developing" countries and involving multiple stakeholders. ${ }^{16}$

However, there are concerns related to the quality of the reports and the underlying review processes (International Institute for Sustainable Development 2019; Kindornay 2019). Furthermore, the consequences of the reporting are unclear, raising the question of the reviews' relevance (Beisheim 2018). Another major limitation to the effectiveness of the HLPF is the fact that the organisations of the UN system, including the Bretton Woods institutions, and other organisations such as the World Trade Organisation are not accountable to the HLPF. They are just invited "to contribute within their respective mandates to the discussions of the forum" (UN 2013, p. 6). Thus, the HLPF as a truly universal body is admittedly a major achievement in itself, but it still lacks the means to live up to its mandate.

The universality of the SDGs and of the HLPF is also a challenge to the other parts of the UN system, with many struggling to overcome their pathdependencies inherited from the pre-2015 world. What used to be the United Nations Development System geared towards "developing countries" needed to turn itself into a United Nations Sustainable Development System, which carries not only many of the terminological but also political and practical questions (Burley and Lindores 2016), in particular to what extent activities geared to domestic implementation in "developed countries" should be included.

In the meantime, first steps could be observed. The United Nations Development Group was turned into the United Nations Sustainable Development Group. The UN's statistical work on the SDGs covers all countries, as do, in principle, major reports on the SDGs, such as the "Global Sustainable Development Report" (UN 2019d). The United Nations Department of Economic and Social Affairs (UN DESA), which traditionally has been the home base of "developing countries" in the UN (Janus and Weinlich 2018), is now taking first steps towards becoming the hub and home for the universal SDGs.

In this context, it is worthwhile to note, for example, that the "Financing for Sustainable Development Report 2019" (UN 2019a) was issued for the first time under this title (it was formerly known as the "Financing for Development Report"), paying tribute to the universality of the 2030 Agenda. The report also covers, at least to a certain extent, domestic issues "developed countries" are faced with when implementing the 2030 Agenda, such as rising inequalities and the gender pay gap, investment-to-GDP ratio, as well as 
public and private debt levels through to sustainable investment and just transitions. With regard to regulatory means, the report also covers, for example, the European Commission's legislative proposals that aim to establish a unified European classification system of sustainable economic activities ("taxonomy") and sees - with regard to integrated national financing frameworks for sustainable development- "clearly scope to do so in both developed and developing countries" (UN 2019a, p. 11). These first steps towards universality come as a pleasant difference to the OECD's "Global Outlook on Financing for Sustainable Development 2019" (Organisation for Economic Co-operation and Development [OECD] 2019c), which reduces its very topic to financing sustainable development in the "developing countries".

However, there is still some way to go from embracing the universality of the SDGs in the UN's conceptual, regulatory/norm-setting, and analytical work to doing so in its operational activities, which remain largely confined to shaping conditions within "developing countries". This requires further reforms, for example of UN DESA (Janus and Weinlich 2018), and may even need changes in mandates, for example of the UN's funds and programmes.

This feature becomes even clearer with the Bretton Woods institutions. Both the World Bank Group (WBG) and the International Monetary Fund (IMF) have a tendency of reductively speaking about the "2030 Development Agenda" instead of the 2030 Agenda for Sustainable Development and maintaining that they serve the SDGs by delivering on their core mandates, which actually predate the 2030 Agenda (International Monetary Fund [IMF] 2019a; World Bank Group 2016). Although the WBG claims to "continue to work in distinct, complementary ways across the full range of low, middle, and high-income member countries [...] allowing transfer of knowledge, experience, and resources across its entire membership", the role of the latter is only seen as to "provide the financial strength of the WBG institutions" (World Bank Group 2016, p. 3). Also, the IMF, whose mandate is-compared to the World Bank Group - truly universal, directs its support for the SDGs "primarily" towards "developing countries" (IMF 2019a, p. 2). With regard to climate change and the IMF, the picture looks a little bit different, as the IMF highlights its "unique role among UN agencies: given its focus on macro and fiscal policies, universal membership and regular interactions with finance ministries" and that it "has a role in providing analysis of (and guidance on) energy pricing and macro-fiscal policies consistent with countries' climate strategies submitted for the Paris Agreement" (IMF 2019b, p. 41). So far, this view has not been transferred to the 2030 Agenda. Thus, the potentially transformative power of the regulatory, promotional, and cooperative instruments of both institutions remains largely untapped with regard to high-income countries.

\subsubsection{OECD and European Union}

As the two major international or, respectively, supranational organisations, the OECD and the European Union (EU), which are comprised in the first place 
of high-income countries, are of critical importance for the implementation of the 2030 Agenda in and between "developed countries". Both committed themselves quite early to contribute towards achieving the SDGs, but they are still struggling to translate this commitment into their core operational activities beyond the realm of development cooperation.

As early as 2016, the OECD adopted an OECD Action Plan on the Sustainable Development Goals calling to "apply an SDG lens to the OECD's strategies and policy tools" (OECD 2016), followed by the adaption of the DAC mandate to the 2030 Agenda (DAC 2017). However, despite the many activities - in particular on measuring distance to the SDG targets in OECD member countries themselves (OECD 2019b) and on "policy coherence for sustainable development" (OECD 2019d)—the SDGs have not even been mentioned once in 30 of the 35 OECD Economic Surveys of member economies issued since 2016. ${ }^{17}$ These OECD flagship products actually reflect the views and policies of both the OECD and the respective countries. Only the surveys on Slovenia (2017), The Netherlands (2018), and Poland (2018) included references to the 2030 Agenda or the SDGs in an at least somewhat systematic way. ${ }^{18}$ The broad neglect of the 2030 Agenda by the Economic Surveys is particularly remarkable since these surveys cover quite a range of issues that are highly relevant for achieving the SDGs within the OECD countries.

A similar pattern could be observed with the EU. On the one hand, the EU championed the SDGs during the negotiation period and was quite quick in translating the 2030 Agenda into the new European Consensus on Development framing the agenda's "implementation [...] in partnership with all developing countries" (European Union [EU] 2017, p. 4). On the other hand, four years after the adoption of the 2030 Agenda, the EU was still reflecting whether the agenda should have a significant bearing at all on domestic European policies (European Commission 2019a; Kloke-Lesch 2018), for example through the EU's budget and regulatory work, which could significantly contribute to shaping conditions within member countries. Evidence shows that half of the member states have some sort of national sustainable development strategy that is actually operational (Niestroy et al. 2019), but that implementation at this level is not supported by communitylevel activities "to mainstream the SDGs in all policies, in particular through the better regulation tools, and other instruments such as structural funds" (Niestroy et al. 2019, p. 6). It was only recently that the elected president of the next European Commission committed to refocus the European Semester-a framework for the coordination of economic policies across the EU-into an instrument that integrates the SDGs (von der Leyen 2019).

\subsubsection{G7 and G20}

The Group of Seven (G7) and the Group of Twenty (G20), as global governance clubs made up by the major industrialised and emerging economies, 
could be places to address the implementation of the 2030 Agenda, both within and between these countries. Instead, the summit history since 2015 has shown a different picture. ${ }^{19}$ The G7 have never endeavoured to systematically embrace the agenda as something of relevance for their domestic policies or their relations with each other. Already in 2015, and only a couple of months before the adoption of the 2030 Agenda, the G7 Summit in Elmau, Germany, positioned the agenda primarily in the traditional development cooperation context. The Ise-Shima/Japan Summit (2016) went one step further by committing "to advance the implementation of the 2030 Agenda, domestically and internationally" but failed to specify this beyond health as well as women's empowerment and gender equality. Thereafter, the G7 summits in 2017 (Taormina, Italy) and 2018 (Charlevoix, Canada) referred to the agenda only marginally and in relation to "developing countries". One could see this reluctance by the G7 as the result of a silent division of labour between G7 and G20 processes, but the developments in the G20 reveal similar patterns.

In distinction from the G7, the G20 brings together major "developed" and "developing" countries that could—and initially did-render it easier to embrace the 2030 Agenda as being relevant to the domestic policies of its members. Immediately after the SDG summit, the 2015 G20 Summit in Antalya, Turkey, committed to "develop an action plan in 2016 to further align our work with the 2030 Agenda". The G20 Action Plan on the 2030 Agenda for Sustainable Development was adopted by the 2016 G20 Summit (Hangzhou, China) and updated in all of the following summits (2017 Hamburg, Germany; 2018 Buenos Aires, Argentina; and 2019 Osaka, Japan). The Action Plan and its updates, including the joint OECD/UNDP report on the "G20 Contribution to the 2030 Agenda" (OECD and United Nations Development Programme 2019), are proof of the great potential the G20 holds in contributing to the implementation of the agenda-also within and between its members-through regulatory work, including norm-setting, and by initiating or promoting cooperation. However, this potential is left largely untapped. The G20's support for the agenda appears to be fading (Bauer et al. 2019). Updates are limited to collective actions, depend on voluntary inputs from responsible work streams, and resemble an inventory rather than a means of driving change. Actions reported are mainly linked to the provision of global public goods and support to "developing countries". Since the presentations on national actions by the G20 members in Annex B to the 2016 Action Plan have not been continued, the only G20 instrument to promote domestic implementation remains the Voluntary Peer Learning Mechanism and the documentation of its results in the updates. From a structural point of view, it is important to note that G20 leaders mandated the Development Working Group "to act as a coordinating body and policy resource for sustainable development across the G20" (G20 Action Plan) but failed to adapt its composition (and name) in line with the upgraded mandate. Composed in the first place of representatives from development cooperation departments 
(on the donors' as well as on the recipients' side), and without participation from departments that are responsible for the domestic implementation of the agenda in the G20 countries, the Development Working Group is in a very difficult position to impact both other G20 work streams and domestic implementation. Thus, the underlying common problem with the G20 and the G7 is a widespread and increasing defensiveness of their members and/or leaders to make domestic implementation of the agenda a common cause between them.

\subsubsection{Bilateral Cooperation and Relations Between "Developed Countries”}

There is little evidence whether, or to what extent, "developed countries" will introduce the 2030 Agenda as a formative feature into the bilateral relations between them. As a case in point, the EU and its member states-as a self-declared "global trail blazer in sustainable development" (European Commission 2019a, p. 31)—committed to advancing the implementation of the 2030 Agenda "globally through the full range of their external actions" (European Commission 2019b, p. 7) but focus, for example, their Joint Synthesis Report "Supporting the Sustainable Development Goals Across the World" (European Commission 2019b) exclusively on "developing countries". It is surprising that this report does not refer to the recent EU-Canada and EU-Japan partnership agreements. Both the Comprehensive Economic and Trade Agreement with Canada and the Economic Partnership Agreement with Japan have dedicated chapters on sustainable development. Both make explicit reference to the 2030 Agenda or the SDGs and the implementation within the respective countries; establish regulatory, promotional, as well as cooperative instruments with regard to trade and investment; and set up institutional structures and processes (e.g. Committees on Trade and Sustainable Development) to oversee their implementation. ${ }^{20}$ The 2019 EU-Canada Summit committed, for example, to reinforce research and innovation cooperation to tackle societal challenges and promote sustainable development. For comparison: also the new Canada-United States-Mexico Agreement resolves to "further the aims of sustainable development" (preamble) and emphasises "the importance of green growth [...] in achieving a competitive and sustainable North American economy" (Agreement on Environmental Cooperation), but it does not refer to the 2030 Agenda. ${ }^{21}$ It is much too early to say whether the provisions in these different agreements will turn into something transformative compared to a low-ambition or mere do-no-harm approach.

The same applies to the new Treaty of Aachen between France and Germany, which also contains specific provisions on the 2030 Agenda, including the creation of a joint platform to deal with transformation processes in both societies. ${ }^{22}$ Another example for introducing the SDGs into a cooperation format between "developed countries" can be found within the Arctic 
Council, where "a closer and more visible tie-in between the Arctic Council's work and the SDGs" was discussed although only with the conclusion "that the Arctic Council could offer valuable guidance in the pursuit of the SDGs in the Arctic, while their implementation is a national responsibility" (Arctic Council 2018, pp. 9-10). Even if some of these small steps indicate a possible direction for the future, they cannot hide the fact that, so far, the 2030 Agenda has not made its way into mainstream relations and cooperation between "developed countries". This, however, needs to change if countries want to live up to the ambition of the agenda and address the emerging geoeconomics and geopolitics of sustainable development, as already becoming evident, for example, in the Arctic or with the ongoing energy transition (International Renewable Energy Agency 2019).

\subsubsection{Conclusion: Towards Mutually Transformative Cooperation in the 2030 World}

Mapping the MoIs of the 2030 Agenda from a functional perspective laid bare a gap between the universal ambitions of the agenda and its lopsided MoIs, which could also be observed during the first steps of implementing the agenda, in particular within and between "developed countries". As the implementation of the agenda within and between these countries is of outmost importance to its overall success, the function of development cooperation ("shaping conditions within (other) countries by using cooperative and promotional instruments") should be exerted also vis-à-vis "developed countries" wherever necessary, accompanied by regulatory instruments designed accordingly ("policy coherence for sustainable development"). For this to happen, the pre-2015 development cooperation model needs to transition into a model of mutually transformative cooperation for the 2030 world.

So far, development cooperation actors have answered to the 2030 Agenda mainly by adopting its terminology and using it as a reinforced narrative underpinning and incrementally broadening their pre-existing business models. The new DAC mandate, for example, speaks of supporting "developing countries" in their implementation of the 2030 Agenda and promoting the importance of global public goods and policy coherence for sustainable development in this regard (DAC 2017). The mandate commits to modernising ODA and improving the development cooperation architecture, but it does not question their basic features inherited from the pre-2015 world with respect to the universality of the 2030 Agenda.

The same phenomenon can be observed with "South-South" cooperation. The Buenos Aires Outcome Document of the Second High-level United Nations Conference on South-South Cooperation (BAPA+40) reaffirmed the basic features and principles of "South-South" cooperation such as mutual benefit, also predating the 2030 Agenda, and put them into relation with the implementation of the 2030 Agenda while also acknowledging "the need to 
enhance the development effectiveness of South-South and triangular cooperation" (UN 2019b, p. 3). The repeated and supportive reference to triangular cooperation $^{23}$ fails to be truly innovative by sticking to an approach aligned to the "requesting developing country" (UN 2019b, p. 8). Thus, the mutuality of cooperation remains confined to the "South-South" dimension, and the role of the "North" remains unidirectional.

Although these conceptual role-assignments are political and ideological constructs that are highly contested by the realities of both "North-South" and "South-South" cooperation (Bergamaschi et al. 2017; Mawdsley 2017), they still frame much of the debate and institutional framings. Figure 7.1 illustrates the main features of the pre-2015 model with, on the one hand, the
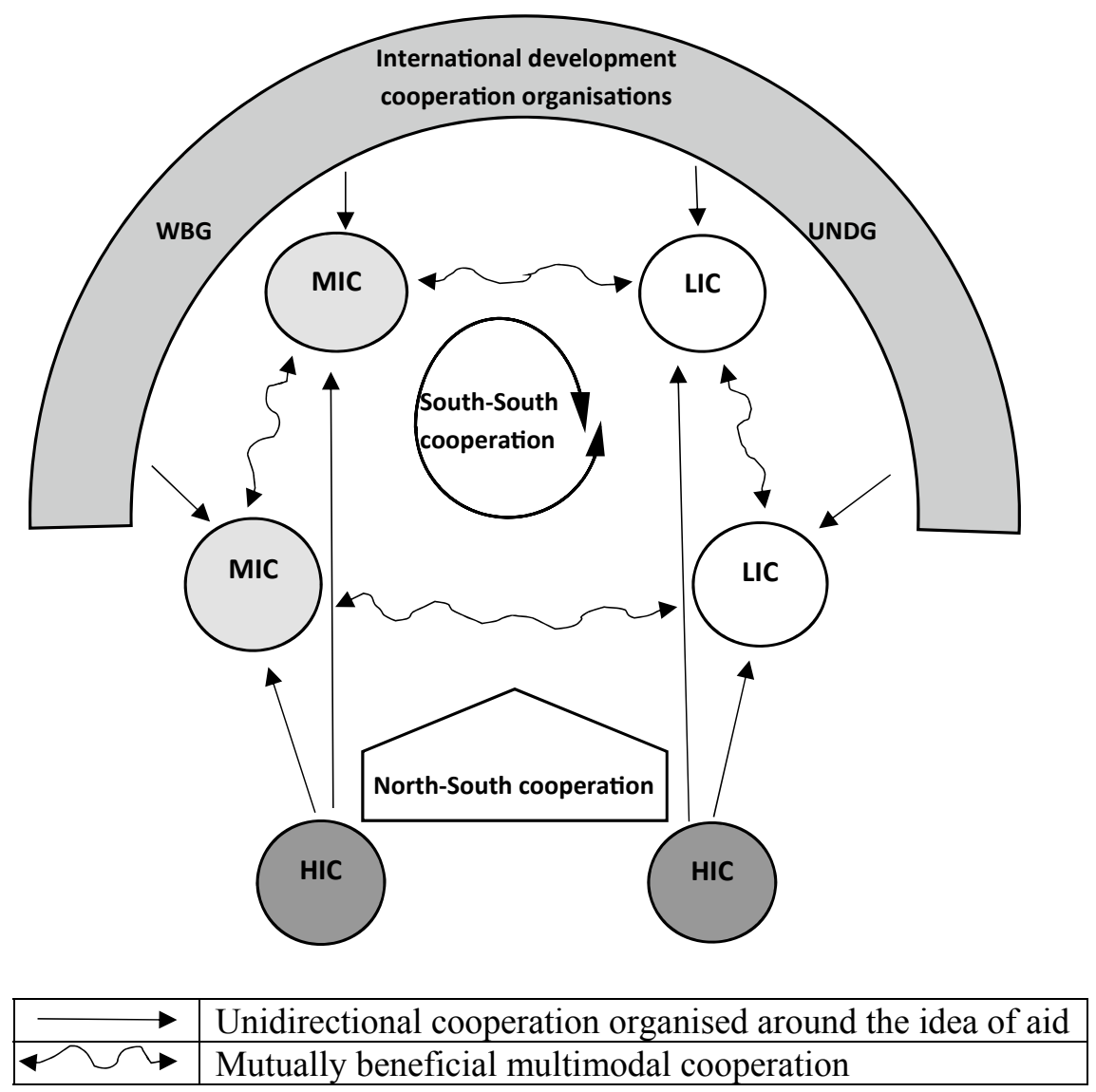

Fig. 7.1 "North-South" and "South-South" cooperation in the pre-2015 world ( Note LIC [low-income country], MIC [middle-income country], WBG [World Bank Group], UNDG [United Nations Development Group], HIC [high-income country]. Source Author) 
unidirectional "North-South" development cooperation basically organised around the idea of aid and, on the other hand, the "South-South" cooperation with mutually beneficial cooperation at its purported conceptual core.

However, under the new paradigm of global development (Horner 2019) being ushered in by the 2030 Agenda, also the concept of development cooperation needs to become global, both in political practice and in scholarly debates. As "the 2030 Agenda constitutes a new basis for international cooperation between all countries", it is evident that "all forms and forums of international cooperation must contribute to implement the 2030 Agenda" (Scholz et al. 2017). The agenda's concept of a Global Partnership for Sustainable Development brings about two significant openings in this regard, firstly by its universality in calling on all countries to implement it, and secondly by highlighting non-governmental actors, including particularly the private sector, and all types of resources in a way not seen before in a comparable document. The former requires "developed countries" to also transform their relations and cooperation with each other, while the latter both mirrors a recent trend in the "North-South" cooperation reflected in the beyond-aid debate (Janus et al. 2015) and allows for fully including "South-South" cooperation with its distinctive features of linking aid, trade, and investment in a mutually beneficial way.

Well thought through, this already entails three core ingredients of a cooperation model for the 2030 world: universality, multimodality, and mutuality. Universality requires incorporating "North-North" cooperation alongside "North-South" and "South-South" cooperation. Multimodality implies that cooperation modes previously confined to relations between specific groups of countries can be applied between all types of countries. Mutuality in a universal cooperation model extends beyond "South-South" and "NorthNorth" cooperation and needs to be introduced well into "North-South" (or "South-North") cooperation. Furthermore, and most importantly, in a 2030 Agenda context, a universal, multimodal, and mutual cooperation needs to be transformational, leading to "transformationality" as a fourth ingredient.

Figure 7.2 illustrates key features of a cooperation model for the 2030 world linking all types of countries (exemplified as high-income, middleincome, and low-income countries) in basically the same ways with each other as well as with the international and supranational cooperation organisations, with mutually transformative cooperation at its core. This relates, on the one hand, to transforming existing cooperation between all types of countries and, on the other hand, introducing new transformative cooperation. Wherever necessary, states as well as international and supranational institutions should use not only regulatory but also promotional and cooperative instruments to shape conditions within - and relations between-countries of all income levels in ways conducive to achieving the SDGs. 


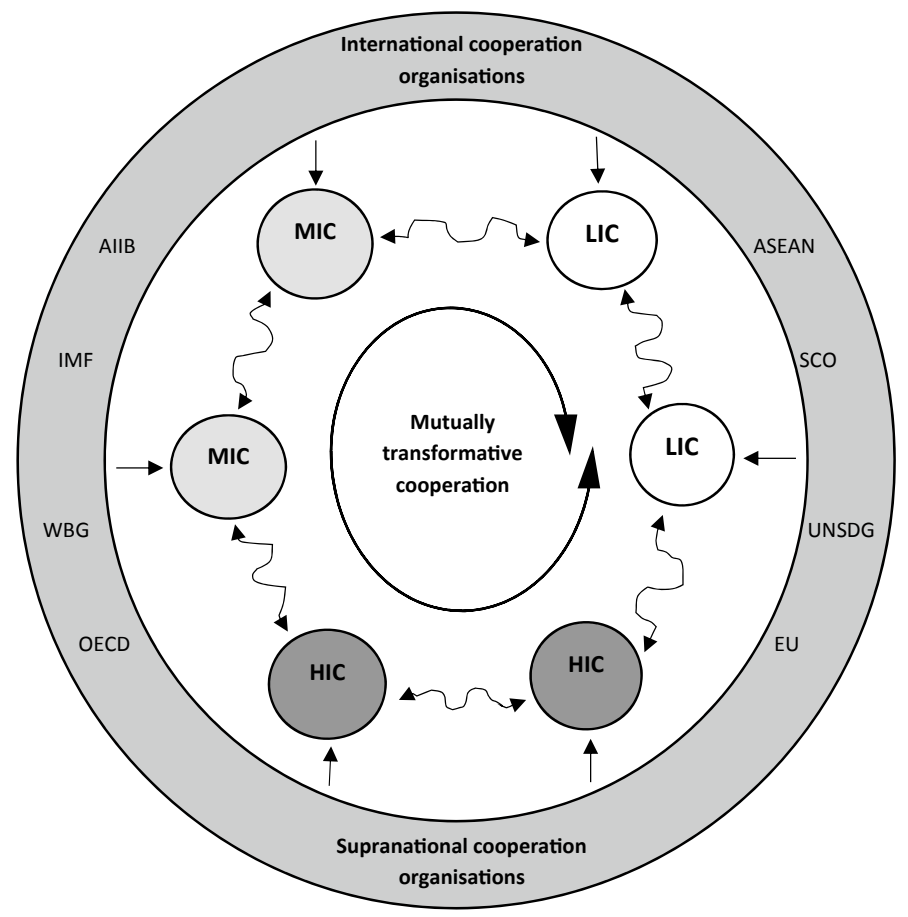

\begin{tabular}{|l|l|}
$\longrightarrow \sim \sim$ & Unidirectional multimodal cooperation \\
\hline$\sim$ & Mutually transformative multimodal cooperation \\
\hline
\end{tabular}

Fig. 7.2 Mutually transformative cooperation in the 2030 world (Note AIIB [Asian Infrastructure Investment Bank], ASEAN [Association of Southeast Asian Nations], HIC [high-income country], LIC [low-income country], MIC [middleincome country], WBG [World Bank Group], UNDG [United Nations Development Group], IMF [International Monetary Fund], OECD [Organisation for Economic Co-operation and Development], EU [European Union], SCO [Shanghai Cooperation Organisation], UNSDG [United Nations Sustainable Development Group]. Source Author)

Development cooperation actors (bi- and multilateral ones alike) from both the "North" and the "South" need to answer whether they want to be part of this new 2030 world of international cooperation by turning themselves into a universal means for delivering transformative change across countries at all levels of income or by just sticking to their normative, geographical, and institutional patterns inherited from the pre-2015 world. International cooperation actors from other governmental departments (both in the "North" and the "South") as well as international and supranational organisations need to decide whether to also introduce the transformative momentum of the 2030 Agenda into their cooperation with (other) "developed countries" or 
to confine this to their cooperation with (other) "developing countries". Both groups of actors have to face the challenge that, in a world of common and collective problems (Haddad 2013), it is increasingly inadequate and inappropriate to stick to a cooperation architecture that separates countries and actors instead of bringing them together as equals working and (re)searching for the global common good. Development cooperation actors as well as other actors should embrace this opportunity. The function of international cooperation in the 2030 world is to jointly deliver change, not aid.

\section{Notes}

1. I put the terms "developing countries" and "developed countries" into quotation marks throughout the text, as these terms have become highly inappropriate given the increasing differentiation between countries. The same applies to the terms "North" and "South". Towards the end of the chapter, I use the terms "high-income", "middle-income", and "low-income" countries to indicate a rough differentiation by income categories, although such a differentiation is still only based on one criterion. In its new Five-Year Strategy, the Overseas Development Institute (ODI) in London decided to "transition from using terms such as 'developing' and 'developed' that create false distinctions between countries, communities and the universal challenges we all face" (Overseas Development Institute 2018).

2. The MDGs were established on the basis of the United Nations Millennium Declaration, adopted in 2000 (UN 2000, 2015a).

3 . The panel was part of the Secretary-General's post-2015 initiative mandated by the 2010 MDG summit (UN, n.d.-a).

4. The OWG was initiated by the Rio+20 conference (UN, n.d.-b).

5. This might also be helpful with resolving some of the other highly contested issues such as "beyond aid" (Janus et al. 2015), the diversity and comparability of "South-South" cooperation (Chaturvedi 2018), and the convergence of "North-South" and "South-South" cooperation (Chaturvedi 2016; Li 2018).

6 . Here and in the following, this paper takes up and refines some observations and propositions the author elaborated on at the end of the 1990s (KlokeLesch 1998a, b).

7. I refer to geographies of development or development cooperation in a socioeconomic sense, not in the sense of physical geographies.

8. Also, ethical approaches to development (Dower 2008; Drydyk 2017) tend to stick to a geographically confined approach.

9. EADI's elaborate definition of development studies covers definitions and goals, learning and teaching, and learning objectives (outcomes). The introductory definition reads as follows: "Development Studies (also known as 'international development studies' or 'international development') is a multiand inter-disciplinary field of study rather than a single discipline. It seeks to understand the interplay between social, economic, political, technological, ecological, cultural and gendered aspects of societal change at the local, national, regional and global levels" (European Association of Development Research and Training Institutes 2017). 
10. Therefore, development studies, also when turning into global development studies, need to maintain intellectual independence and "the SDGs should not become a straightjacket" for them (Melber 2017).

11. For some time (until 2005) the DAC tried to accommodate the difficulties by introducing the term "official aid" for countries and territories in transition (including Russia), which also included more advanced developing countries. Today, all the countries concerned (except Russia) are either on the DAC List of ODA recipients or have become-some after being on the list for some years-members of the EU (OECD, n.d.).

12. The increasingly relevant private philanthropic actors the Bill \& Melinda Gates Foundation are left aside in this contribution but could be subsumed under the non-governmental actors that are potentially subject to regulatory and promotional functions of external governmental activities (see Table 7.1).

13. While focussing the analysis on the 62 explicit MoIs, it has to be acknowledged that many SDGs and their targets are, in fact, means themselves or intermediate goals contributing to the achievement of higher goals, rendering the distinction between goals and targets on the one hand, and MOI on the other hand, somehow artificial (Elder et al. 2016). In addition to the 62 explicit MoIs, 19 out of the (other) 107 SDG targets can be seen as process targets (Development Assistance Committee [DAC] 2016).

14. This is particularly surprising, as at least the targets under SDG 8 (Decent work and economic growth) and SDG 12 (Responsible consumption and production) call on "developed countries" to take the lead with improving global resource efficiency in consumption and production and endeavouring to decouple economic growth from environmental degradation, in accordance with the 10-Year Framework of Programmes on Sustainable Consumption and Production.

15. The HLPF was mandated in 2012 by the outcome document of the Rio+ 20 conference (UN 2012).

16. Until 2019 roughly 140 countries (out of them around 30 "developed countries") have submitted voluntary national reviews to the HLPF, indicating at least a certain interest in showing domestic efforts of implementation in both "developing" and "developed countries" (UN, n.d.-c).

17. The Economic surveys can be found on the OECD website at http://www. oecd.org/economy/surveys/.

18. The surveys on the Czech Republic (2018) and Denmark (2019) made just marginal references.

19. For the G7 and G20 Summit documents, turn to http://www.g7.utoronto.ca/ and http://www.g20.utoronto.ca/.

20. Also the EU-Mercosur Association Agreement is designed in a similar way. The EU agreements with Canada, Japan, and Mercosur can be found at https:// eeas.europa.eu/headquarters/headquarters-homepage_en.

21. For a brief assessment of the Environmental Cooperation Agreement under CUSMA, see Cosbey (2019); the texts of the draft agreements can be found here: https://www.international.gc.ca/trade-commerce/trade-agreements-acc ords-commerciaux/agr-acc/cusma-aceum/text-texte/toc-tdm.aspx?lang=eng.

22. See https://www.auswaertiges-amt.de/blob/2179780/ccd486958222bd5a49 0d42c57dd7ed03/190118-download-aachenervertrag-data.pdf. 
23. Triangular cooperation is conceptualised as a "collaboration in which traditional donor countries and multilateral organizations facilitate South-South initiatives" (UN Office for South-South Cooperation 2019).

\section{ANNEX}

\begin{tabular}{|c|c|}
\hline & Annex: Means of implementation of the 2030 Agenda \\
\hline \multirow{2}{*}{$\begin{array}{l}\text { SDG } 1 \text { No } \\
\text { Poverty }\end{array}$} & $\begin{array}{l}\text { 1.a Ensure significant mobilization of resources from a variety of sources, including through enhanced } \\
\text { development cooperation, in order to provide adequate and predictable means for developing countries, in } \\
\text { particular least developed countries, to implement programmes and policies to end poverty in all its } \\
\text { dimensions }\end{array}$ \\
\hline & $\begin{array}{l}\text { 1.b Create sound policy frameworks at the national, regional and international levels, based on pro-poor } \\
\text { and gender-sensitive development strategies, to support accelerated investment in poverty eradication } \\
\text { actions }\end{array}$ \\
\hline \multirow{3}{*}{$\begin{array}{l}\text { SDG } 2 \text { Zero } \\
\text { Hunger }\end{array}$} & $\begin{array}{l}\text { 2.a Increase investment, including through enhanced international cooperation, in rural infrastructure, } \\
\text { agricultural research and extension services, technology development and plant and livestock gene banks } \\
\text { in order to enhance agricultural productive capacity in developing countries, in particular least developed } \\
\text { countries }\end{array}$ \\
\hline & $\begin{array}{l}\text { 2.b Correct and prevent trade restrictions and distortions in world agricultural markets, including through } \\
\text { the parallel elimination of all forms of agricultural export subsidies and all export measures with } \\
\text { equivalent effect, in accordance with the mandate of the Doha Development Round }\end{array}$ \\
\hline & $\begin{array}{l}\text { 2.c Adopt measures to ensure the proper functioning of food commodity markets and their derivatives and } \\
\text { facilitate timely access to market information, including on food reserves, in order to help limit extreme } \\
\text { food price volatility }\end{array}$ \\
\hline \multirow{4}{*}{$\begin{array}{l}\text { SDG } 3 \text { Good } \\
\text { Health and } \\
\text { Well-being }\end{array}$} & $\begin{array}{l}\text { 3.a Strengthen the implementation of the World Health Organization Framework Convention on Tobacco } \\
\text { Control in all countries, as appropriate }\end{array}$ \\
\hline & $\begin{array}{l}\text { 3.b Support the research and development of vaccines and medicines for the communicable and non- } \\
\text { communicable diseases that primarily affect developing countries, provide access to affordable essential } \\
\text { medicines and vaccines, in accordance with the Doha Declaration on the TRIPS Agreement and Public } \\
\text { Health, which affirms the right of developing countries to use to the full the provisions in the Agreement } \\
\text { on Trade-Related Aspects of Intellectual Property Rights regarding flexibilities to protect public health, } \\
\text { and, in particular, provide access to medicines for all }\end{array}$ \\
\hline & $\begin{array}{l}\text { 3.c Substantially increase health financing and the recruitment, development, training and retention of the } \\
\text { health workforce in developing countries, especially in least developed countries and small island } \\
\text { developing States }\end{array}$ \\
\hline & $\begin{array}{l}\text { 3.d Strengthen the capacity of all countries, in particular developing countries, for early warning, risk } \\
\text { reduction and management of national and global health risks }\end{array}$ \\
\hline \multirow{3}{*}{$\begin{array}{l}\text { SDG } 4 \text { Quality } \\
\text { Education }\end{array}$} & $\begin{array}{l}\text { 4.a Build and upgrade education facilities that are child, disability and gender sensitive and provide safe, } \\
\text { non-violent, inclusive and effective learning environments for all }\end{array}$ \\
\hline & $\begin{array}{l}\text { 4.b By } 2020 \text {, substantially expand globally the number of scholarships available to developing countries, } \\
\text { in particular least developed countries, small island developing States and African countries, for } \\
\text { enrolment in higher education, including vocational training and information and communications } \\
\text { technology, technical, engineering and scientific programmes, in developed countries and other } \\
\text { developing countries }\end{array}$ \\
\hline & $\begin{array}{l}\text { 4.c By } 2030 \text {, substantially increase the supply of qualified teachers, including through international } \\
\text { cooperation for teacher training in developing countries, especially least developed countries and small }\end{array}$ \\
\hline
\end{tabular}




\begin{tabular}{|c|c|}
\hline & island developing States \\
\hline \multirow{3}{*}{$\begin{array}{l}\text { SDG } 5 \text { Gender } \\
\text { Equality }\end{array}$} & $\begin{array}{l}\text { 5.a Undertake reforms to give women equal rights to economic resources, as well as access to ownership } \\
\text { and control over land and other forms of property, financial services, inheritance and natural resources, in } \\
\text { accordance with national laws }\end{array}$ \\
\hline & $\begin{array}{l}\text { 5.b Enhance the use of enabling technology, in particular information and communications technology, to } \\
\text { promote the empowerment of women }\end{array}$ \\
\hline & $\begin{array}{l}\text { 5.c Adopt and strengthen sound policies and enforceable legislation for the promotion of gender equality } \\
\text { and the empowerment of all women and girls at all levels }\end{array}$ \\
\hline \multirow{2}{*}{$\begin{array}{c}\text { SDG 6 Clean } \\
\text { Water and } \\
\text { Sanitation }\end{array}$} & $\begin{array}{l}\text { 6.a By 2030, expand international cooperation and capacity-building support to developing countries in } \\
\text { water- and sanitation-related activities and programmes, including water harvesting, desalination, water } \\
\text { efficiency, wastewater treatment, recycling and reuse technologies }\end{array}$ \\
\hline & $\begin{array}{c}\text { 6.b Support and strengthen the participation of local communities in improving water and sanitation } \\
\text { management }\end{array}$ \\
\hline \multirow{2}{*}{$\begin{array}{c}\text { SDG 7 } \\
\text { Affordable and } \\
\text { Clean Energy }\end{array}$} & $\begin{array}{l}\text { 7.a By 2030, enhance international cooperation to facilitate access to clean energy research and } \\
\text { technology, including renewable energy, energy efficiency and advanced and cleaner fossil-fuel } \\
\text { technology, and promote investment in energy infrastructure and clean energy technology }\end{array}$ \\
\hline & $\begin{array}{l}\text { 7.b By 2030, expand infrastructure and upgrade technology for supplying modern and sustainable energy } \\
\text { services for all in developing countries, in particular least developed countries, small island developing } \\
\text { States and landlocked developing countries, in accordance with their respective programmes of support }\end{array}$ \\
\hline \multirow{2}{*}{$\begin{array}{l}\text { SDG } 8 \text { Decent } \\
\text { Work and } \\
\text { Economic } \\
\text { Growth }\end{array}$} & $\begin{array}{l}\text { 8.a Increase Aid for Trade support for developing countries, in particular least developed countries, } \\
\text { including through the Enhanced Integrated Framework for Trade-related Technical Assistance to Least } \\
\text { Developed Countries }\end{array}$ \\
\hline & $\begin{array}{c}\text { 8.b By 2020, develop and operationalize a global strategy for youth employment and implement the } \\
\text { Global Jobs Pact of the International Labour Organization }\end{array}$ \\
\hline \multirow{3}{*}{$\begin{array}{l}\text { SDG } 9 \text { Industry, } \\
\text { Innovation, and } \\
\text { Infrastructure }\end{array}$} & $\begin{array}{l}\text { 9.a Facilitate sustainable and resilient infrastructure development in developing countries through } \\
\text { enhanced financial, technological and technical support to African countries, least developed countries, } \\
\text { landlocked developing countries and small island developing States }\end{array}$ \\
\hline & $\begin{array}{l}\text { 9.b Support domestic technology development, research and innovation in developing countries, } \\
\text { including by ensuring a conducive policy environment for, inter alia, industrial diversification and value } \\
\text { addition to commodities }\end{array}$ \\
\hline & $\begin{array}{l}\text { 9.c Significantly increase access to information and communications technology and strive to provide } \\
\text { universal and affordable access to the Internet in least developed countries by } 2020\end{array}$ \\
\hline \multirow{2}{*}{$\begin{array}{l}\text { SDG } 10 \\
\text { Reducing } \\
\text { Inequality }\end{array}$} & $\begin{array}{l}\text { 10.a Implement the principle of special and differential treatment for developing countries, in particular } \\
\text { least developed countries, in accordance with World Trade Organization agreements }\end{array}$ \\
\hline & $\begin{array}{l}\text { 10.b Encourage official development assistance and financial flows, including foreign direct investment, } \\
\text { to States where the need is greatest, in particular least developed countries, African countries, small island } \\
\text { developing States and landlocked developing countries, in accordance with their national plans and } \\
\text { programmes }\end{array}$ \\
\hline
\end{tabular}




\begin{tabular}{|c|c|}
\hline & $\begin{array}{l}\text { 10.c By 2030, reduce to less than } 3 \text { per cent the transaction costs of migrant remittances and eliminate } \\
\text { remittance corridors with costs higher than } 5 \text { per cent }\end{array}$ \\
\hline \multirow{3}{*}{$\begin{array}{l}\text { SDG 11 } \\
\text { Sustainable } \\
\text { Cities and } \\
\text { Communities }\end{array}$} & $\begin{array}{l}\text { 11.a Support positive economic, social and environmental links between urban, peri-urban and rural areas } \\
\text { by strengthening national and regional development planning }\end{array}$ \\
\hline & $\begin{array}{l}\text { 11.b By } 2020 \text {, substantially increase the number of cities and human settlements adopting and } \\
\text { implementing integrated policies and plans towards inclusion, resource efficiency, mitigation and } \\
\text { adaptation to climate change, resilience to disasters, and develop and implement, in line with the Sendai } \\
\text { Framework for Disaster Risk Reduction 2015-2030, holistic disaster risk management at all levels }\end{array}$ \\
\hline & $\begin{array}{l}\text { 11.c Support least developed countries, including through financial and technical assistance, in building } \\
\text { sustainable and resilient buildings utilizing local materials }\end{array}$ \\
\hline \multirow{3}{*}{$\begin{array}{c}\text { SDG 12 } \\
\text { Responsible } \\
\text { Consumption } \\
\text { and Production }\end{array}$} & $\begin{array}{l}\text { 12.a Support developing countries to strengthen their scientific and technological capacity to move } \\
\text { towards more sustainable patterns of consumption and production }\end{array}$ \\
\hline & $\begin{array}{l}\text { 12.b Develop and implement tools to monitor sustainable development impacts for sustainable tourism } \\
\text { that creates jobs and promotes local culture and products }\end{array}$ \\
\hline & $\begin{array}{l}\text { 12.c Rationalize inefficient fossil-fuel subsidies that encourage wasteful consumption by removing } \\
\text { market distortions, in accordance with national circumstances, including by restructuring taxation and } \\
\text { phasing out those harmful subsidies, where they exist, to reflect their environmental impacts, taking fully } \\
\text { into account the specific needs and conditions of developing countries and minimizing the possible } \\
\text { adverse impacts on their development in a manner that protects the poor and the affected communities }\end{array}$ \\
\hline \multirow{2}{*}{$\begin{array}{l}\text { SDG } 13 \text { Climate } \\
\text { Action }\end{array}$} & $\begin{array}{l}\text { 13.a Implement the commitment undertaken by developed-country parties to the United Nations } \\
\text { Framework Convention on Climate Change to a goal of mobilizing jointly } \$ 100 \text { billion annually by } 2020 \\
\text { from all sources to address the needs of developing countries in the context of meaningful mitigation } \\
\text { actions and transparency on implementation and fully operationalize the Green Climate Fund through its } \\
\text { capitalization as soon as possible }\end{array}$ \\
\hline & $\begin{array}{l}\text { 13.b Promote mechanisms for raising capacity for effective climate change-related planning and } \\
\text { management in least developed countries and small island developing States, including focusing on } \\
\text { women, youth and local and marginalized communities }\end{array}$ \\
\hline \multirow{3}{*}{$\begin{array}{l}\text { SDG } 14 \text { Life } \\
\text { Below Water }\end{array}$} & $\begin{array}{l}\text { 14.a Increase scientific knowledge, develop research capacity and transfer marine technology, taking into } \\
\text { account the Intergovernmental Oceanographic Commission Criteria and Guidelines on the Transfer of } \\
\text { Marine Technology, in order to improve ocean health and to enhance the contribution of marine } \\
\text { biodiversity to the development of developing countries, in particular small island developing States and } \\
\text { least developed countries }\end{array}$ \\
\hline & 14.b Provide access for small-scale artisanal fishers to marine resources and markets \\
\hline & $\begin{array}{l}\text { 14.c Enhance the conservation and sustainable use of oceans and their resources by implementing } \\
\text { international law as reflected in the United Nations Convention on the Law of the Sea, which provides the } \\
\text { legal framework for the conservation and sustainable use of oceans and their resources, as recalled in } \\
\text { paragraph } 158 \text { of "The future we want" }\end{array}$ \\
\hline \multirow{2}{*}{$\begin{array}{l}\text { SDG } 15 \text { Life On } \\
\text { Land }\end{array}$} & $\begin{array}{l}\text { 15.a Mobilize and significantly increase financial resources from all sources to conserve and sustainably } \\
\text { use biodiversity and ecosystems }\end{array}$ \\
\hline & $\begin{array}{l}\text { 15.b Mobilize significant resources from all sources and at all levels to finance sustainable forest } \\
\text { management and provide adequate incentives to developing countries to advance such management, }\end{array}$ \\
\hline
\end{tabular}




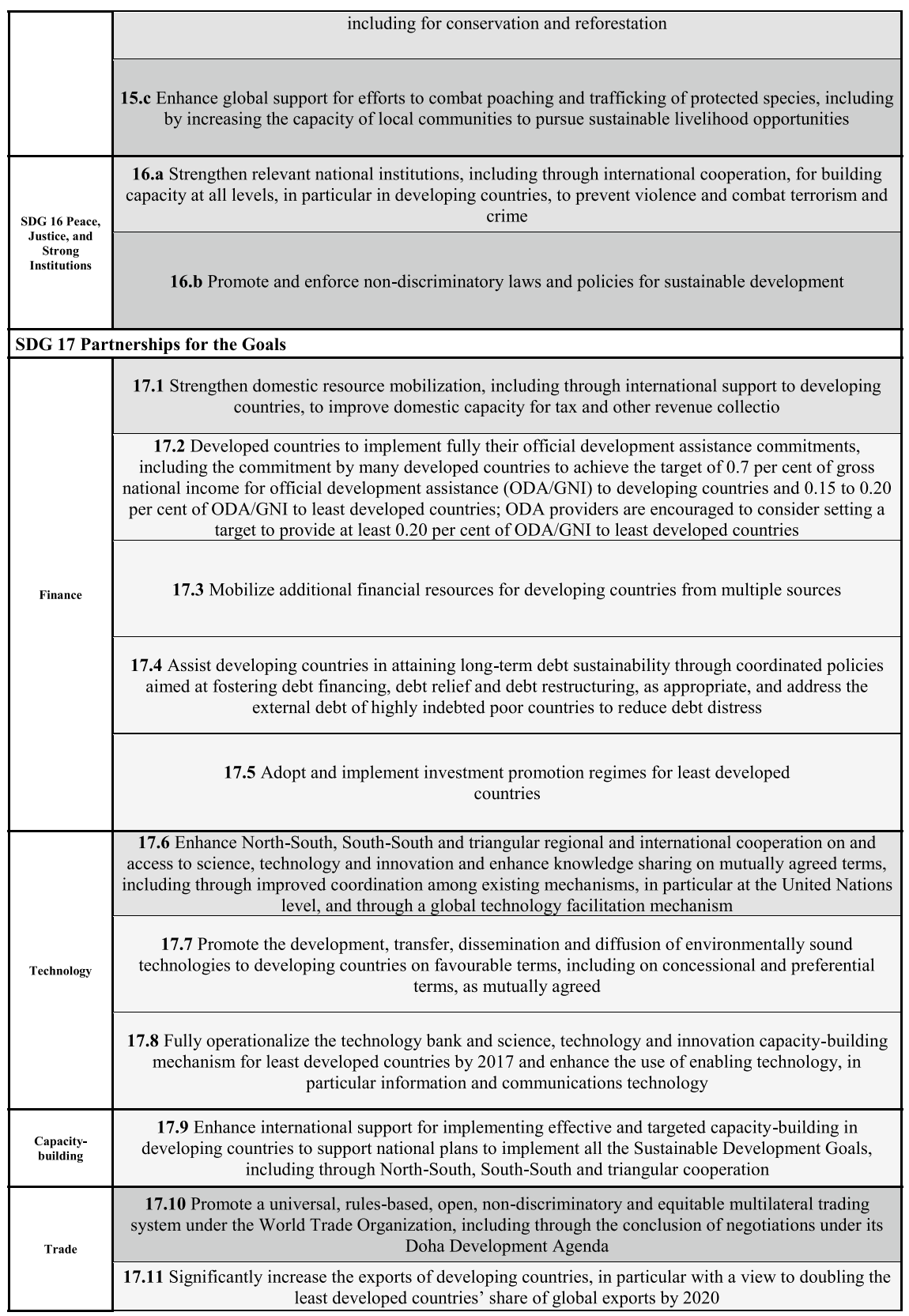




\begin{tabular}{|c|c|c|c|c|c|}
\hline & $\begin{array}{r}17.12 \\
\text { least } \mathrm{d} \\
\text { pre }\end{array}$ & $\begin{array}{l}\text { loped countries, consist } \\
\text { ential rules of origin ap! }\end{array}$ & $\begin{array}{l}\text { of duty-free and } \\
\text { with World Trade } \\
\text { able to imports fror } \\
\text { nd contribute to fac }\end{array}$ & $\begin{array}{l}\text { ta-free market access or } \\
\text { ganization decisions, inc } \\
\text { east developed countries } \\
\text { ating market access }\end{array}$ & $\begin{array}{l}\text { lasting basis for all } \\
\text { ding by ensuring that } \\
\text { e transparent and }\end{array}$ \\
\hline \multirow{7}{*}{ Systemic issues } & \multicolumn{5}{|c|}{$\begin{array}{l}\text { 17.13 Enhance global macroeconomic stability, including through policy coordination and policy } \\
\text { coherence }\end{array}$} \\
\hline & \multicolumn{5}{|c|}{ 17.14 Enhance policy coherence for sustainable development } \\
\hline & \multicolumn{5}{|c|}{$\begin{array}{l}\text { 17.15 Respect each country's policy space and leadership to establish and implement policies for poverty } \\
\text { eradication and sustainable development }\end{array}$} \\
\hline & \multicolumn{5}{|c|}{$\begin{array}{l}\text { 17.16 Enhance the Global Partnership for Sustainable Development, complemented by multi-stakeholder } \\
\text { partnerships that mobilize and share knowledge, expertise, technology and financial resources, to support } \\
\text { the achievement of the Sustainable Development Goals in all countries, in particular developing countries }\end{array}$} \\
\hline & \multicolumn{5}{|c|}{$\begin{array}{l}\text { 17.17 Encourage and promote effective public, public-private and civil society partnerships, building on } \\
\text { the experience and resourcing strategies of partnerships }\end{array}$} \\
\hline & \multicolumn{5}{|c|}{$\begin{array}{l}\text { 17.18 By } 2020 \text {, enhance capacity-building support to developing countries, including for least developed } \\
\text { countries and small island developing States, to increase significantly the availability of high-quality, } \\
\text { timely and reliable data disaggregated by income, gender, age, race, ethnicity, migratory status, disability, } \\
\text { geographic location and other characteristics relevant in national contexts }\end{array}$} \\
\hline & \multicolumn{5}{|c|}{$\begin{array}{l}\text { 17.19 By 2030, build on existing initiatives to develop measurements of progress on sustainable } \\
\text { development that complement gross domestic product, and support statistical capacity-building in } \\
\text { developing countries }\end{array}$} \\
\hline \multicolumn{2}{|c|}{$\begin{array}{l}\text { Exclusively oriented } \\
\text { towards so-called } \\
\text { developed countries }\end{array}$} & $\begin{array}{l}\text { Universally oriented with } \\
\text { an additional focus on so- } \\
\text { called developed countries }\end{array}$ & Universally oriented & $\begin{array}{l}\text { Universally oriented with } \\
\text { an additional focus on so- } \\
\text { called developing countries }\end{array}$ & $\begin{array}{l}\text { Exclusively oriented } \\
\text { towards so-called } \\
\text { developing countries }\end{array}$ \\
\hline \multicolumn{2}{|l|}{0} & 0 & 25 & 9 & 28 \\
\hline
\end{tabular}

\section{Source Author, based on UN (2015c)}




\section{REFERENCES}

Alff, H., \& Hornidge, A.-K. (2019). “Transformation” in international development studies: Across disciplines, knowledge hierarchies and oceanic spaces. In I. Baud, E. Basile, T. Kontinen, \& S. von Itter (Eds.), Building development studies for the new millennium. EADI Global Development Series (pp. 141-161). Basingstoke: Palgrave Macmillan.

Almond, G. (1960). Introduction: A functional approach to comparative politics. In G. A. Almond \& J. S. Coleman (Eds.), The politics of the developing areas (pp. 3-64). Princeton, NJ: Princeton University Press.

Arctic Council. (2018, March 22-23). Report: SAO plenary meeting. https://oaarch ive.arctic-council.org/handle/11374/2165.

Baud, I., Basile, E., Kontinen, T., \& von Itter, S. (Eds.) (2019). Building development studies for the new millennium (EADI Global Development Series). Basingstoke: Palgrave Macmillan.

Bauer, S., Berger, A., \& Iacubato, G. (2019). With or without you: How the G20 could advance global action towards climate-friendly sustainable development (Briefing Paper 10/2019). Bonn: German Development Institute / Deutsches Institut für Entwicklungspolitik (DIE).

Beisheim, M. (2018, October). UN reforms for the 2030 Agenda-Are the HLPF's working methods and practices "fit for purpose"? (SWP Research Paper 9). Berlin: Stiftung Wissenschaft und Politik.

Bergamaschi, I., Moore, P., \& Tickner, A. B. (Eds.) (2017). South-South cooperation beyond the myths: Rising donors, new aid practices? London: Palgrave Macmillan.

Bexell, M., \& Jönsson, K. (2017). Responsibility and the United Nations' Sustainable Development Goals. Forum for Development Studies, 44(1), 13-29.

Burchi, F., de Muro, P., \& Kollar, E. (2018). Constructing well-being and poverty dimensions on political grounds. Social Indicators Research, 137(2), 441-462.

Burley, J., \& Lindores, D. (2016). The UN development system and its operational activities for development: Updating the definitions. https://www.cbd.int/financial/ doc/un-terminology2016.pdf.

Chaturvedi, S. (2016). The development compact: A theoretical construct for SouthSouth cooperation. International Studies, 53(1), 15-43.

Chaturvedi, S. (2018). South-South cooperation: Theoretical perspectives and empirical realities. https://www.ssc-globalthinkers.org/node/160.

Cooper, N., \& French, D. (2018). SDG 17: Partnerships for the Goals-Cooperation within the context of a voluntarist framework. In D. French \& L. J. Kotzé (Eds.), Sustainable Development Goals: Law, theory and implementation (pp. 271-303). Cheltenham: Edward Elgar Publishing.

Cosbey, A. (2019, February). Weighing up the environmental cooperation agreement under the Canada-United States-Mexico Agreement (IISD Policy Brief). https://www.iisd.org/library/weighing-environmental-cooperation-agreem ent-under-canada-united-states-mexico-agreement.

CSO Partnership. (2017). CSO recommendations on the DAC's new purpose code for the "facilitation of orderly, safe, regular and responsible migration and mobility". http:// cso.csopartnership.org/6504-2/. 
DAC (Development Assistance Committee). (2016, January). An SDG-based results framework for development co-operation. Draft note by the results team of the development co-operation directorate. https://www.oecd.org/dac/peer-reviews/SDGbased $\% 20$ results\%20framework.docx.

DAC. (2017, October 31). DAC high-level communiqué. https://www.oecd.org/ dac/DAC-HLM-2017-Communique.pdf.

Dalrymple, S. (2016). New aid rules allow for the inclusion of a wider set of peace and security activities. http://devinit.org/post/new-aid-rules-allow-for-the-inclusion-ofa-wider-set-of-peace-and-security-activities /.

Dodds, F., Donoghue, D., \& Roesch, J. (2017). Negotiating the Sustainable Development Goals. London: Routledge.

Dower, N. (2008). The nature and scope of development ethics. Journal of Global Ethics, 4(3), 183-193.

Drydyk, J. (2017). Ethical issues in development. In J. Grugel \& D. Hammet (Eds.), The Palgrave handbook of international development (pp. 55-76). London: Palgrave Macmillan.

Elder, M., Bengtsson, M., \& Akenji, L. (2016). An optimistic analysis of the means of implementation for Sustainable Development Goals: Thinking about goals as means. Sustainability, 8(9), 962.

EU. (2017). The new European consensus on development-"our world, our dignity, our future”. https://ec.europa.eu/europeaid/sites/devco/files/european-consen sus-on-development-final-20170626_en.pdf.

European Association of Development Research and Training Institutes. (2017). Definition of development studies. https://www.eadi.org/typo3/fileadmin/Documents/ Publications/EADI_Definition_Development_Studies_2017.pdf.

European Commission. (2019a). Reflection paper: Towards a sustainable Europe by 2030. https://ec.europa.eu/commission/sites/beta-political/files/rp_sustainable_ europe_30-01_en_web.pdf.

European Commission. (2019b). Supporting the Sustainable Development Goals across the world: Joint synthesis report of the European Union and its member states. https:// ec.europa.eu/europeaid/sites/devco/files/jsr-report-20190717_en.pdf.

Fialho, D., \& van Bergeijk, P. A. G. (2017). The proliferation of developing country classifications. The Journal of Development Studies, 53(1), 99-115.

Fukuda-Parr, S., \& McNeill, D. (2019). Knowledge and politics in setting and measuring the SDGs: Introduction to special issue. Global Policy, 10(1), 5-15.

Gulrajani, N., \& Calleja, R. (2019). The principled aid index (Policy Briefing). London: Overseas Development Institute.

Haddad, L. (2013). Development research: The shape of things to come? http:/ /www.dev elopmenthorizons.com/2013/08/development-research-shape-of-things-to.html.

Haynal, G. (2002). DOA: Diplomacy on the ascendant in the age of disintermediation. https://scholarsprogram.wcfia.harvard.edu/files/fellows/files/haynal.pdf.

High Level Panel. (2013). A new global partnership: Eradicate poverty and transform economies through sustainable development. The Report of the High-Level Panel of Eminent Persons on the Post-2015 Development Agenda (HLP). https://www.un. org/sg/sites/www.un.org.sg/files/files/HLP_P2015_Report.pdf.

Horner, R. (2019). Towards a new paradigm of global development? Beyond the limits of international development. Progress in Human Geography, 1-22. https:// doi.org/10.1177/0309132519836158. 
IMF (International Monetary Fund). (2019a). Review of implementation of IMF commitments in support of the 2030 Agenda for Sustainable Development (IMF Policy Paper). Washington, DC: Author.

IMF. (2019b). Fiscal policies for Paris climate strategies-From principle to practice (IMF Policy Paper). Washington, DC: Author.

International Institute for Sustainable Development. (2019). HLPF 2019 highlights. Earth Negotiations Bulletin (ENB), 33(51).

International Renewable Energy Agency. (2019). A new world: The geopolitics of the energy transformation. Abu Dhabi: Author.

Janus, H., Klingebiel, S., \& Paulo, S. (2015). Beyond aid: A conceptual perspective on the transformation of development cooperation. Journal of International Development, 27(2), 155-169.

Janus, H., \& Weinlich, S. (2018). A mountain worth climbing: Reforming the UN Department of Economic and Social Affairs (Briefing Paper 20/2018). Bonn: German Development Institute / Deutsches Institut für Entwicklungspolitik (DIE).

Kaul, I. (2017). Providing global public goods-What role for the multilateral development banks? (ODI Report). London: Overseas Development Institute.

Kindornay, S. (2019). Progressing national SDG implementation: An independent assessment of the voluntary national review reports submitted to the United Nations High-level Political Forum in 2018. Ottawa: Canadian Council for International Co-operation.

King, M. (2016). Broadening the global development framework post 2015: Embracing policy coherence and global public goods. European Journal of Development Research, 28(1), 13-29.

Kisangani, E. F., \& Pickering, J. (2015). Soldiers and development aid. Journal of Peace Research, 52(2), 215-227.

Klingebiel, S., Mahn, T., \& Negre, M. (Eds.). (2016). The fragmentation of aid: Concepts, measurements and implications for development cooperation. London: Palgrave Macmillan.

Kloke-Lesch, A. (1998a). Funktionale Positionsbestimmung der Entwicklungspolitik. Internationale Politik und Gesellschaft, 3(1998), 324-332.

Kloke-Lesch, A. (1998b). The position of development policy: A functional definition. In D. Messner (Ed.), New perspectives of international and German development policy (INEF-Report 33) (pp. 36-47). Duisburg: Institut für Entwicklung und Frieden.

Kloke-Lesch, A. (2016). The G20 and the Sustainable Development Goals (SDGs): Reflections on future roles and tasks. In Chongyang Institute for Financial Studies (Ed.), G20 and global governance: Blue book of G20 Think Tank 2015-2016 (pp. 5571). Beijing: CITIC Publ. Group.

Kloke-Lesch, A. (2018). Why is the EU failing to champion the SDGs? Horizons: Journal of International Relations and Sustainable Development, 12(2018), 144159.

Kloke-Lesch, A. (2019). Globale Entwicklungspolitik: Politikberatung zwischen aidcommunity und global public goods. In S. Falk, M. Glaab, A. Römmele, H. Schober, \& M. Thunert (Eds.), Handbuch Politikberatung (pp. 417-434). Wiesbaden: Springer.

Li, Y. (2018). Assessment of South-South cooperation and the global narrative on the eve of BAPA + 40 (Research Paper 88). Geneva: South Centre. 
Martens, J. (2019). Revisiting the hardware of sustainable development. In B. Adams, C. A. Billorou, R. Bissio, C. Y. Ling, K. Donald, J. Martens, \& S. Prato (Eds.), Reshaping governance for sustainability: Transforming institutions-Shifting powerStrengthening rights (Global Civil Society Report on the 2030 Agenda and the SDGs, pp. 11-19). Bonn: Global Policy Forum Europe e.V.

Mawdsley, E. (2017). National interests and the paradox of foreign aid under austerity: Conservative governments and the domestic politics of international development since 2010. The Geographical Journal, 183(3), 223-232.

Melber, H. (2017). Development studies and the SDGs-Mapping an agenda (EADI Policy Paper Series). Bonn: European Association of Development Research and Training Institutes.

Messner, D., \& Scholz, I. (2018). Globale Gemeinwohlorientierung als Fluchtpunkt internationaler Kooperation für nachhaltige Entwicklung - ein Perspektivwechsel. Zeitschrift Für Außen- Und Sicherheitspolitik, 11(4), 561-572.

Mitchell, I. (2021). Measuring development cooperation and the quality of aid. In S. Chaturvedi et al., (Eds.), The Palgrave handbook of development cooperation for achieving the 2030 agenda: Contested collaboration (pp. 247-270).

Mönks, J., Carbonnier, G., Mellet, A., \& de Haan, L. (2019). Novel perceptions on development studies: International review and consultations towards a renewed vision. In I. Baud, E. Basile, T. Kontinen, \& S. von Itter (Eds.), Building development studies for the new millennium. EADI Global Development Series (pp. 217-241). Basingstoke: Palgrave Macmillan.

Niestroy, I., Hege, E., Dirth, E., Zondervan, R., \& Derr, K. (2019). Europe's approach to implementing the Sustainable Development Goals: Good practices and the way forward. http://www.europarl.europa.eu/thinktank/en/document.html?reference= EXPO_STU\%282019\%29603473.

OECD (Organisation for Economic Co-operation and Development). (2016a). Better policies for 2030: An OECD action plan on the Sustainable Development Goals. https://www.oecd.org/dac/Better\%20Policies\%20for\%202030.pdf.

OECD. (2019b). Measuring distance to the SDG targets 2019: An assessment of where OECD countries stand. Paris: OECD Publishing.

OECD. (2019c). Global outlook on financing for sustainable development 2019. https://www.oecd.org/dac/financing-sustainable-development/development-fin ance-topics/Global-Outlook-on-Financing-for-SD-2019.pdf.

OECD. (2019d). Policy coherence for sustainable development 2019. https://www. oecd.org/gov/pcsd/policy-coherence-for-sustainable-development-highlights2019.pdf.

OECD. (n.d.). History of DAC Lists of aid recipient countries. http://www.oecd. org/development/financing-sustainable-development/development-finance-standa rds/historyofdaclistsofaidrecipientcountries.htm\#Concepts.

OECD \& United Nations Development Programme (UNDP). (2019). G20 contribution to the 2030 Agenda-Progress and way forward. https://g20.org/pdf/docume nts/en/oecd-undp_report_g20_contribution_2030_agenda.pdf.

Overseas Development. (2018). Five-year strategy. https://www.odi.org/sites/odi. org.uk/files/long-form-downloads/strategy_booklet_final_web_0.pdf.

Schmidt-Traub, G., Hoff, H., \& Bernlöhr, M. (2019, July 15). International spillovers and the Sustainable Development Goals (SDGs) (SDSN Policy Brief). Paris: Sustainable Development Solutions Network. 
Scholz, I., Esteves, P., Yuefen, L., \& Anbumozhi, V. (2017). Reforming international cooperation towards transformative change. https://www.g20-insights.org/pol icy_briefs/reforming-international-cooperation-towards-transformative-change/.

Schönberg, J. (2019). Imagining postcolonial development studies: Reflections on positionalities and research practices. In I. Baud, E. Basile, T. Kontinen, \& S. von Itter (Eds.), Building development studies for the new millennium. EADI Global Development Series (pp. 97-116). Basingstoke: Palgrave Macmillan.

Stafford-Smith, M., Griggs, D., Gaffney, O., Ullah, F., Reyers, B., Kanie, N., et al. (2017). Integration: The key to implementing the Sustainable Development Goals. Sustainability Science, 12(6), 911-919.

UN (United Nations). (2000). United Nations millennium declaration. Resolution adopted by the General Assembly (A/RES/55/2). https://www.un.org/en/ development/desa/population/migration/generalassembly/docs/globalcompact/ A_RES_55_2.pdf.

UN. (2012, July 27). The future we want. Resolution adopted by the General Assembly (A/RES/66/288*). https://www.un.org/en/development/desa/popula tion/migration/generalassembly/docs/globalcompact/A_RES_66_288.pdf.

UN. (2013, July 9). Format and organizational aspects of the High-level Political Forum on Sustainable Development. Resolution adopted by the General Assembly (A/RES/67/290). https://www.un.org/ga/search/view_doc.asp?sym bol=A/RES $/ 67 / 290 \&$ Lang=E.

UN. (2015a). The Millennium Development Goals report 2015. New York, NY: Author.

UN. (2015b). Outcome Document of the Third International Conference on Financing for Development: Addis Ababa Action Agenda. General Assembly (A/CONF.227/L.1). https://www.un.org/africarenewal/sites/www.un.org.africa renewal/files/N1521991.pdf.

UN. (2015c). Transforming our world: The 2030 Agenda for Sustainable Development. Resolution adopted by the General Assembly (A/RES/70/1). https://www.un. org/en/development/desa/population/migration/generalassembly/docs/global compact/A_RES_70_1_E.pdf.

UN. (2019a). Financing for sustainable development report 2019: Inter-agency Task Force on Financing for Development. New York, NY: Author.

UN. (2019b). Buenos Aires Outcome Document of the Second High-level United Nations Conference on South-South Cooperation. Resolution adopted by the General Assembly (A/73/L.80). https://digitallibrary.un.org/record/3799433.

UN. (2019c). Special edition: Progress towards the Sustainable Development Goals. Report of the Secretary-General (E/2019/68). https://unstats.un.org/sdgs/files/rep ort $/ 2019$ /secretary-general-sdg-report-2019-EN.pdf.

UN. (2019d). Global Sustainable Development Report 2019. New York, NY: Author.

UN. (n.d.-a). The Secretary-General's High-Level Panel of Eminent Persons on the Post-2015 Development Agenda. https://www.un.org/sg/en/management/hlppos t2015.shtml.

UN. (n.d.-b). Open Working Group on Sustainable Development Goals. https://sustai nabledevelopment.un.org/owg.html.

UN. (n.d.-c). Voluntary national reviews. https://sustainabledevelopment.un.org/ vnrs/.

UN Office for South-South Cooperation. (2019). About South-South and triangular cooperation. https://www.unsouthsouth.org/about/about-sstc/. 
Van Bergeijk, P. A. G., \& van Marrewijk, C. (2013). Heterogeneity and development: An agenda. The Journal of International Trade \& Economic Development, 22(1), $1-10$.

Veltmeyer, H., \& Wise, R. D. (Eds.). (2018). Critical development studies: An introduction. Black Point, Nova Scotia: Fernwood Publishing.

Von der Heijden, K., Olsen, S., \& Scott, A. (2014). From solidarity to universalityHow global interdependence impacts the post-2015 development agenda (Background Paper 1). London: Independent Research Forum.

Von der Leyen, U. (2019). A union that strives for more-My agenda for Europe. https://ec.europa.eu/commission/interim_en.

World Bank Group. (2016). Forward look: A vision for the World Bank Group in 2030 (DC2016-0008). http://pubdocs.worldbank.org/en/545241485963738 230/DC2016-0008.pdf.

Open Access This chapter is licensed under the terms of the Creative Commons Attribution 4.0 International License (http://creativecommons.org/licenses/by/4.0/), which permits use, sharing, adaptation, distribution and reproduction in any medium or format, as long as you give appropriate credit to the original author(s) and the source, provide a link to the Creative Commons license and indicate if changes were made.

The images or other third party material in this chapter are included in the chapter's Creative Commons license, unless indicated otherwise in a credit line to the material. If material is not included in the chapter's Creative Commons license and your intended use is not permitted by statutory regulation or exceeds the permitted use, you will need to obtain permission directly from the copyright holder.

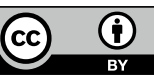

